\title{
House Prices and the Stance of Monetary Policy
}

\author{
Marek Jarociński and Frank R. Smets
}

\begin{abstract}
This paper estimates a Bayesian vector autoregression for the U.S. economy that includes a housing sector and addresses the following questions: Can developments in the housing sector be explained on the basis of developments in real and nominal gross domestic product and interest rates? What are the effects of housing demand shocks on the economy? How does monetary policy affect the housing market? What are the implications of house price developments for the stance of monetary policy? Regarding the latter question, we implement a Céspedes et al. (2006) version of a monetary conditions index. (JEL E3 E4)
\end{abstract}

Federal Reserve Bank of St. Louis Review, July/August 2008, 90(4), pp. 339-65.

T he current financial turmoil, triggered by increasing defaults in the subprime mortgage market in the United States, has reignited the debate about the effect of the housing market on the economy at large and about how monetary policy should respond to booming house prices. ${ }^{1}$ Reviewing the role of housing investment in post-WWII business cycles in the United States, Leamer (2007, p. 53) concludes that "problems in housing investment have contributed $26 \%$ of the weakness in the economy in the year before the eight recessions" and suggests that, in the most recent boom and bust period, highly stimulative monetary policy by the Fed first contributed to a booming housing market and subsequently led to an abrupt contraction as the yield curve inverted. Similarly, using counterfactual simulations, Taylor (2007)

1 See the papers presented at the August 30-September 1, 2007, Federal Reserve Bank of Kansas City economic symposium Housing, Housing Finance, and Monetary Policy in Jackson Hole, Wyoming; http://www.kc.frb.org/home/subwebnav.cfm?level=3\&theID=105 $48 \&$ SubWeb=5. A literature survey is presented in Mishkin (2007). shows that the period of exceptionally low shortterm interest rates in 2003 and 2004 (compared with a Taylor rule) may have substantially contributed to the boom in housing starts and may have led to an upward spiral of higher house prices, falling delinquency and foreclosure rates, more favorable credit ratings and financing conditions, and higher demand for housing. As the short-term interest rates returned to normal levels, housing demand fell rapidly, bringing down both construction and house price inflation. In contrast, Mishkin (2007) illustrates the limited ability of standard models to explain the most recent housing developments and emphasizes the uncertainty associated with housing-related monetary transmission channels. He also warns against leaning against rapidly increasing house prices over and above their effects on the outlook for economic activity and inflation and suggests instead a preemptive easing of policy when a house price bubble bursts, to avoid a large loss in economic activity. Even more recently, Kohn (2007, p. 3) says

Marek Jarociński is an economist and Frank R. Smets is Deputy Director General of Research at the European Central Bank. The authors thank their discussants, Bob King and Steve Cecchetti, for their insightful comments.

(C) 2008, The Federal Reserve Bank of St. Louis. The views expressed in this article are those of the author(s) and do not necessarily reflect the views of the Federal Reserve System, the Board of Governors, the regional Federal Reserve Banks, or the European Central Bank. Articles may be reprinted, reproduced, published, distributed, displayed, and transmitted in their entirety if copyright notice, author name(s), and full citation are included. Abstracts, synopses, and other derivative works may be made only with prior written permission of the Federal Reserve Bank of St. Louis. 
I suspect that, when studies are done with cooler reflection, the causes of the swing in house prices will be seen as less a consequence of monetary policy and more a result of the emotions of excessive optimism followed by fear experienced every so often in the marketplace through the ages...Low policy interest rates early in this decade helped feed the initial rise in house prices. However, the worst excesses in the market probably occurred when short-term interest rates were already well on their way to more normal levels, but longer-term rates were held down by a variety of forces.

In this paper, we review the role of the housing market and monetary policy in U.S. business cycles since the second half of the 1980s using an identified Bayesian vector autoregressive (BVAR) model. We focus on the past two decades for a number of reasons. First, following the "Great Inflation" of the 1970s, inflation measured by the gross domestic product (GDP) deflator has been relatively stable between 0 and 4 percent since the mid-1980s. As discussed by Clarida, Galí, and Gertler (1999) and many others, this is likely partly the result of a more systematic monetary policy approach geared at maintaining price stability. Second, there is significant evidence that the volatility of real GDP growth has fallen since 1984 (e.g., McConnell and Pérez-Quirós, 2000). An important component of this fall in volatility has been a fall in the volatility of housing investment. Moreover, Mojon (2007) has shown that a major contribution to the "Great Moderation" has been a fall in the correlation between interest ratesensitive consumer investment, such as housing investment, and the other components of GDP. This suggests that the role of housing investment in the business cycle may have changed since the deregulation of the mortgage market in the early 1980s. Indeed, Dynan, Elmendorf, and Sichel (2005) find that the interest rate sensitivity of housing investment has fallen over this period.

We use BVAR to perform three exercises. First, we analyze the housing boom and bust in the new millennium using conditional forecasts by asking this question: Conditional on the esti- mated model, can we forecast the housing boom and bust based on observed real GDP, prices, and short- and long-term interest rate developments? This is a first attempt at understanding the sources of the swing in residential construction and house prices in the new millennium. In the benchmark VAR, our finding is that housing market developments can only partially be explained by nominal and real GDP developments. In particular, the strong rise in house prices in 2000 and the peak of house prices in 2006 cannot be explained. Adding the federal funds rate to the information set helps forecast the housing boom. Interestingly, most of the variations in the term spread can also be explained on the basis of the short-term interest rate, but there is some evidence of a long-term interest rate conundrum in 2005 and 2006. As a result, observing the long-term interest rate also provides some additional information to explain the boom in house prices.

Second, using a mixture of zero and sign restrictions, we identify the effects of housing demand, monetary policy, and term spread shocks on the economy. We find that the effects of housing demand and monetary policy shocks are broadly in line with the existing empirical literature. We also analyze whether these shocks help explain the housing boom and its effect on the wider economy. We find that both housing market and monetary policy shocks explain a significant fraction of the construction and house price boom, but their effects on overall GDP growth and inflation are relatively contained.

Finally, in the light of the above findings and following a methodology proposed by Céspedes et al. (2006), we explore the use of a monetary conditions index (MCI), which includes the federal funds rate, the long-term interest rate spread, and real house prices, to measure the stance of monetary policy. The idea of measuring monetary conditions by taking an appropriate weight of financial asset prices was pioneered by the Bank of Canada and the Reserve Bank of New Zealand in the 1990s. As both countries are small open economies, these central banks worried about how changes in the value of the exchange rate may 
affect the monetary policy stance. ${ }^{2}$ The idea was to construct a weighted index of the short-term interest rate and the exchange rate, where the weights reflected the relative effect of those monetary conditions on an intermediate or final target variable, such as the output gap, output growth, or inflation. A number of authors have extended the idea of an MCI to other asset prices, arguing that those asset prices may be equally or more important than the exchange rate. A prominent example is Goodhart and Hofmann (2007), who argue that real house prices should receive a significant weight because of their large effect on the economy and inflation in particular. In contrast to this literature, the crucial feature of the MCI methodology proposed by Céspedes et al. (2006) is that it takes into account that interest rates and house prices are endogenous variables that systematically respond to the state of the economy. As a result, their MCI can more naturally be interpreted as a measure of the monetary policy stance. Using the identified BVAR, we apply the methodology to question whether the rise in house prices and the fall in long-term interest rates led to an implicit easing of monetary policy in the United States.

In the next section, we present two estimated BVAR specifications. We then use both BVARs to calculate conditional forecasts of the housing market boom and bust in the new millennium. In the third section, we identify housing demand, monetary policy, and term spread shocks and investigate their effect on the U.S. economy. Finally, in the fourth section we develop MCIs and show using a simple analytical example how the methodology works and why it is important to take into account the endogeneity of short- and long-term interest rates and house prices with respect to the state of the economy. We then use the estimated BVARs to address whether long-term interest rates and house prices play a significant role in measuring the stance of monetary policy. A final section contains some conclusions and discusses some of the shortcomings and areas for future research.

\footnotetext{
2 See, for example, Freedman (1994 and 1995a,b) and Duguay (1994).
}

\section{A BVAR WITH HOUSING FOR THE U.S. ECONOMY}

In this section, we present the results from estimating a nine-variable BVAR of order five for the U.S. economy. In addition to standard variables, such as real GDP, the GDP deflator, commodity prices, the federal funds rate, and M2, we include real consumption, real housing investment, real house prices, and the long-term interest rate spread. To measure house price inflation, we use the nationwide Case-Shiller house price index, which limits our sample to 1987:Q1-2007:Q2. The two estimated BVAR specifications are as follows: One is a traditional VAR in levels (LVAR) that uses a standard Minnesota prior. The other is a differences VAR (DVAR) that is specified in growth rates and uses priors about the steady state (see Villani, 2008).

More specifically, in the LVAR, the vector of endogenous variables is given by

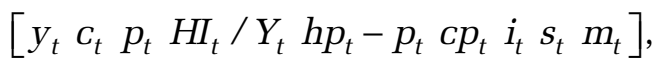

where all variables are in logs, with the exception of the federal funds rate $\left(i_{t}\right)$, the long-term interest rate spread $\left(s_{t}\right)$, and the housing investment share of GDP $\left(H I_{t} / Y_{t}\right)$; $y_{t}$ is real GDP; $c_{t}$ is real consumption; $p_{t}$ is the GDP deflator; $h p_{t}$ is house prices; $c p_{t}$ is commodity prices; and $m_{t}$ is the money stock. $^{3}$

In the DVAR, the vector of endogenous variables is instead given by

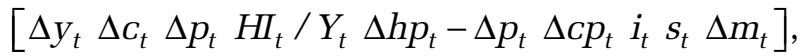

where $\Delta$ is the difference operator and the BVAR is parameterized in terms of deviations from steady state.

The main difference between the two specifications is related to the assumptions one makes about the steady state of the endogenous variables. The advantage of the DVAR with a prior on the joint steady state is that it guarantees that the growth rates are reasonable and mutually consistent in the long run, in spite of the short sample

\footnotetext{
3 See the data appendix for the sources of the time series.
} 


\section{Table 1}

\section{Prior and Posterior Means and Standard Deviations of the Steady States in the DVAR}

\begin{tabular}{|c|c|c|c|c|c|c|c|c|c|}
\hline Variable & $\begin{array}{c}\text { Real GDP } \\
\text { growth }\end{array}$ & $\begin{array}{c}\text { Real } \\
\text { consumption } \\
\text { growth }\end{array}$ & $\begin{array}{c}\text { GDP } \\
\text { deflator } \\
\text { inflation }\end{array}$ & $\begin{array}{c}\text { Housing } \\
\text { investment/ } \\
\text { GDP }\end{array}$ & $\begin{array}{l}\text { House } \\
\text { price } \\
\text { growth }\end{array}$ & $\begin{array}{c}\text { Commodity } \\
\text { price } \\
\text { growth }\end{array}$ & $\begin{array}{c}\text { Federal } \\
\text { funds } \\
\text { rate }\end{array}$ & $\begin{array}{c}\text { Term } \\
\text { spread }\end{array}$ & $\begin{array}{l}\text { Money } \\
\text { growth }\end{array}$ \\
\hline Prior mean & 2.50 & 2.50 & 2.00 & 4.50 & 0.00 & 2.00 & 4.50 & 1.00 & 4.50 \\
\hline Standard deviation & 0.50 & 0.71 & 0.20 & 1.00 & 2.00 & 2.00 & 0.62 & 1.00 & 1.00 \\
\hline Posterior mean & 2.96 & 3.23 & 2.21 & 4.51 & 1.52 & 2.00 & 5.05 & 1.42 & 4.35 \\
\hline Standard deviation & 0.22 & 0.22 & 0.15 & 0.07 & 1.08 & 1.54 & 0.34 & 0.24 & 0.51 \\
\hline
\end{tabular}

used in the estimation. The cost is that it discards important sample information contained in the LVAR variables. As we discuss below, this may be the main reason behind the larger error bands around the DVAR impulse responses and conditional projections. Although the forecasts of the LVAR match the data better at shorter horizons, the longer-run unconditional forecasts it produces make less sense from an economic point of view. Because these considerations may matter for assessing the monetary policy stance, we report the findings using both specifications.

In both cases the estimation is Bayesian. In the case of the DVAR, it involves specifying a prior on the steady state of the VAR and a Minnesota prior on dynamic coefficients, as introduced in Villani (2008). The Minnesota prior uses standard settings, which are the same as the settings used for the LVAR. In the DVAR, the informative prior on the steady state serves two roles: First, it regularizes the inference on the steady states of variables. Without it, the posterior distribution of the steady states is ill-specified because of the singularity at the unit root. Second, and this is our innovation with respect to the approach of Villani (2008), through it we use economic theory to specify prior correlations between steady states. The steady-state nominal interest rate is, by the Fisher equation, required to be the sum of the steady-state inflation rate and the equilibrium real interest rate. The steady-state real interest rate is, in turn, required to be equal to the steadystate output growth rate plus a small error reflecting time preference and a risk premium. The steady-state output and consumption growth rates are also correlated a priori, as we think of them as having a common steady state.

The prior and posterior means and standard deviations of the steady states in the DVAR are given in Table 1.

Figure 1 plots the data we use, as well as their estimated steady-state values from the DVAR. The steady-state growth rate of real GDP is estimated to be close to 3 percent over the sample period.

Average GDP deflator inflation is somewhat above 2 percent. The steady-state housing investmentto-GDP ratio is about 4.5 percent. During the new millennium construction boom, the ratio rose by 1 percentage point, peaking at 5.5 percent in 2005 before dropping below its long-term average in the second quarter of 2007. Developments in real house prices mirror the developments in the construction sector. The estimated steady-state real growth rate of house prices is 1.5 percent over the sample period. However, changes in real house prices were negative during the early-1990s recession. The growth rate of house prices rose above average in the late 1990s and accelerated significantly above its estimated steady state, reaching a maximum annual growth rate of more than 10 percent in 2005 before falling abruptly to negative growth rates in 2006 and 2007. Turning to interest rate developments, the estimated steadystate nominal interest rate is around 5 percent. The estimated steady-state term spread, that is, the difference between the 10-year bond yield rate and the federal funds rate, is 1.4 percent. In the analysis below, we will focus mostly on the boom and bust period in the housing market starting in 2000. 


\section{Figure 1}

\section{Data Used and Their Estimated Steady-State Values from the DVAR}
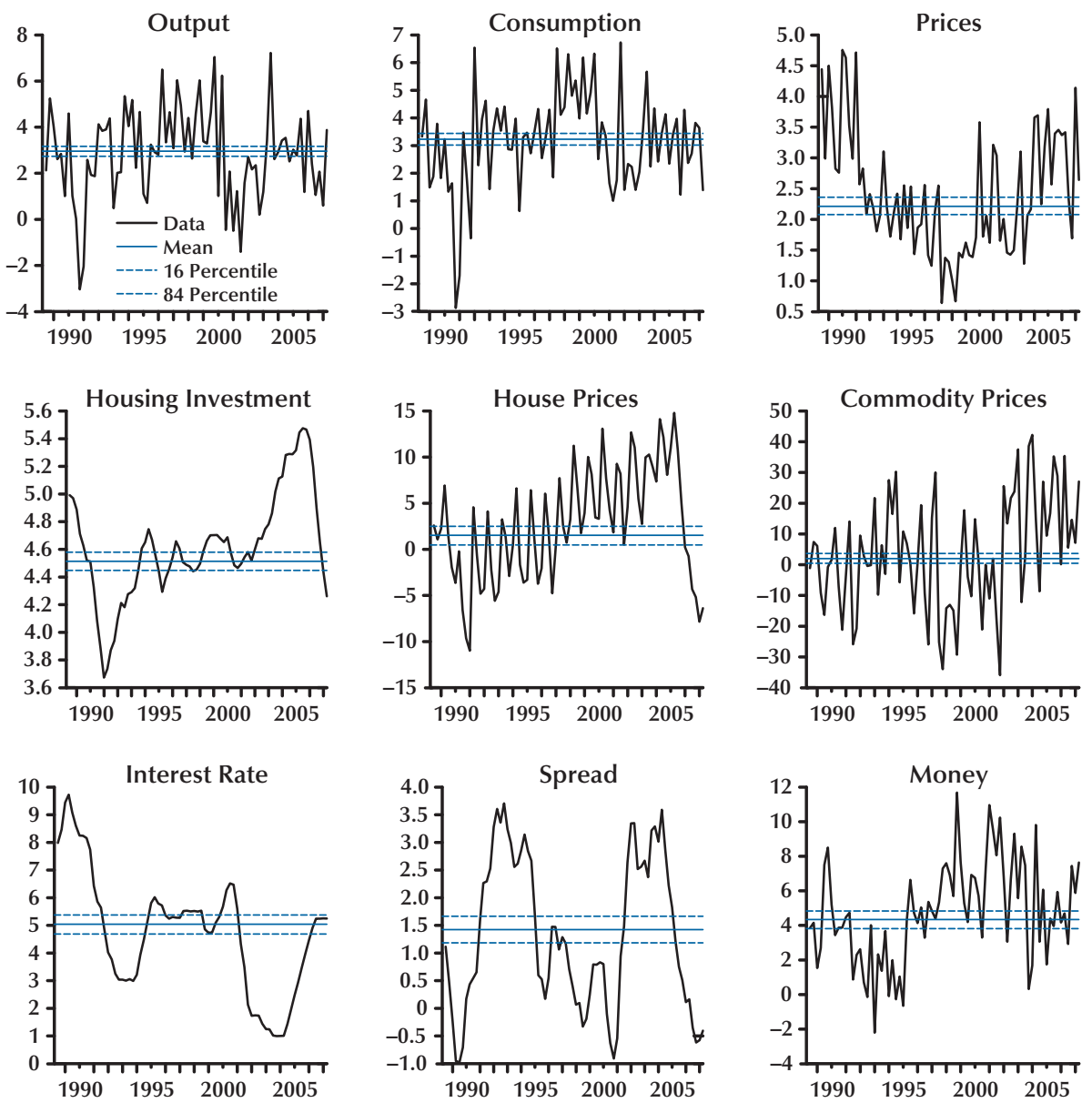

Using both BVAR specifications, we then ask the following question: Can we explain developments in the housing market based on observed developments in real and nominal GDP and the short- and long-term interest rates? To answer this question we make use of the conditional forecasting methodology developed by Doan, Litterman, and Sims (1984) and Waggoner and Zha (1999).

Figures 2A and 2B report the results for the DVAR and the LVAR, respectively, focusing on the post-2000 period. Each figure shows the actual developments of the housing investment-to-GDP ratio (first column) and the annual real growth rate of house prices (second column). Dotted black lines denote unconditional forecasts, and blue lines denote conditional forecasts, conditioning on observed real and nominal GDP (first row), observed real and nominal GDP and the federal funds rate (second row), and observed real and nominal GDP, the federal funds rate, and the term spread (third row). Note that this is an in-sample analysis in that the respective VARs are estimated over the full sample period. The idea behind increasing the information set is to see to what extent short- and long-term interest rates provide information about developments in the housing 
Figure 2A

\section{Housing Investment-to-GDP Ratio and Annual House Price Growth Rate, 1995-2007: Actual Data and Unconditional and Conditional Forecasts from the DVAR}
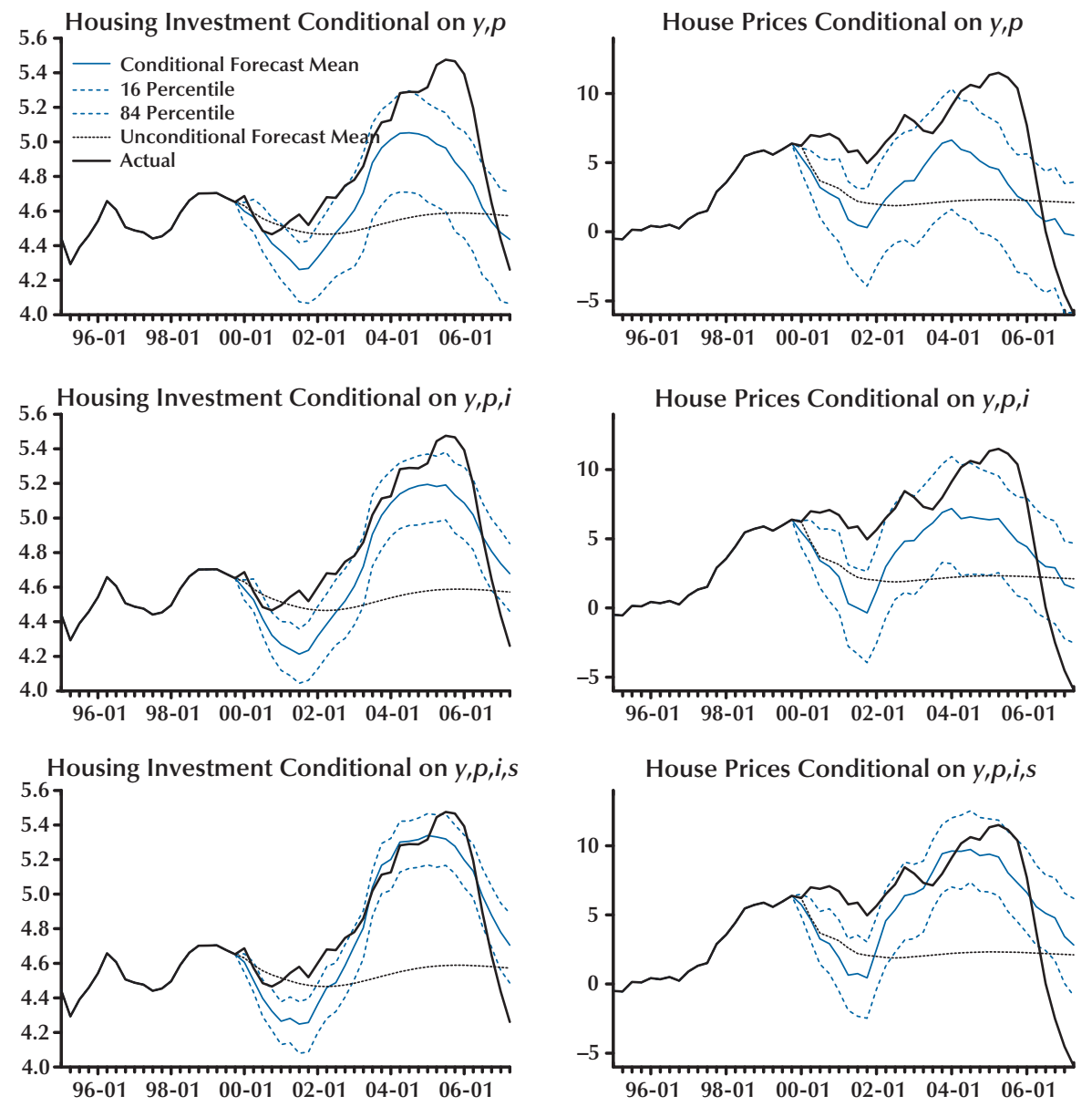

market, in addition to the information already contained in real and nominal GDP.

A number of interesting observations can be made. First, as discussed above, the unconditional forecasts of housing investment and real house price growth are quite different in both VARs. The DVAR projects the housing investment-to-GDP ratio to fluctuate mildly around its steady state, while the growth rate of house prices is projected to return quite quickly to its steady state of 1.5 percent from the relatively high level of growth of more than 5 percent at the end of 1999. The LVAR instead captures some of the persistent in- sample fluctuations and projects a further rise in housing investment and the growth rate of house prices before it returns close to the sample mean in 2007.

Second, based on the DVAR in Figure 2A, neither GDP developments nor short- or long-term interest rates can explain why real house prices continued to grow at rates above 5 percent following the slowdown of the economy in 2000 and 2001. Real and nominal GDP developments can explain an important fraction of the housing boom in 2002 and 2003, but they cannot account for the 10 percent acceleration of house prices in 2004 


\section{Figure 2B}

\section{Housing Investment-to-GDP Ratio and Annual House Price Growth Rate, 1995-2007: Actual Data and Unconditional and Conditional Forecasts from the LVAR}
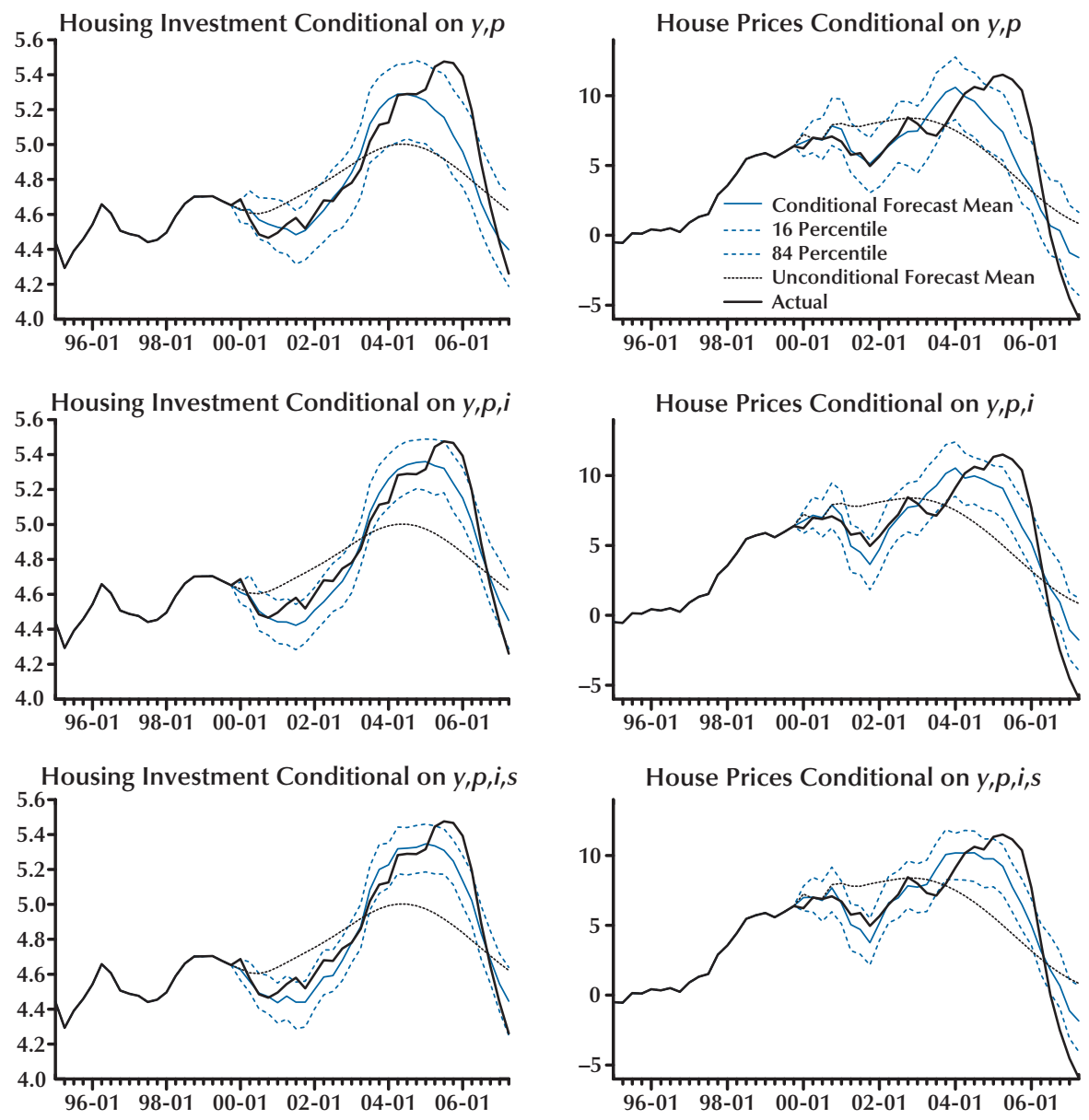

and 2005. The low level of short- and long-term interest rates in 2004 and 2005 helps explain the boom in those years. In particular, toward the end of 2004 and in 2005, the unusually low level of long-term interest rates helps account for the acceleration in house prices. According to this model, there is some evidence of a conundrum: In this period, long-term interest rates are lower than would be expected on the basis of observed shortterm interest rates. The ability to better forecast the boom period comes, however, at the expense of a larger unexplained undershooting of house prices and housing investment toward the end of the sample. Overall, these results suggest that the unusually low level of short- and long-term interest rates may have contributed to the boom in U.S. housing markets in the new millennium.

Third, the LVAR results in Figure 2B are, however, less clear. The part of the housing boom that cannot be explained by developments in real and nominal GDP is smaller. Moreover, adding short- and long-term interest rates to the data set does not change the picture very significantly. These findings suggest that the results of this analysis partly depend on the assumed steady-state behavior of the housing market and interest rates. 


\section{IDENTIFYING HOUSING DEMAND, MONETARY POLICY, AND TERM SPREAD SHOCKS}

To add a bit more structure to the analysis, in this section we identify housing demand, monetary policy, and term spread shocks and analyze their effect on the economy. We use a mixture of a recursive identification scheme and sign restrictions. As usual, monetary policy shocks are identified by zero restrictions. They are assumed to affect economic activity and prices with a onequarter lag, but they may have an immediate effect on the term spread and the money stock. The housing demand shock is a shock that affects housing investment and house prices contemporaneously and in the same direction. Moreover, its immediate effect on output is roughly equal to the increase in housing investment (i.e., this shock has no contemporaneous effect on the other components of output taken together).

We use sign restrictions to impose this identification scheme. ${ }^{4}$ For simplicity, we also assume that the housing demand shock affects the GDP deflator only with a lag. The shock that affects housing investment and house prices in opposite directions can be interpreted as a housing supply shock. However, it turns out that this shock explains only a small fraction of developments in the housing market, so we will not explicitly discuss this shock. Figure 3 shows for the DVAR (shaded areas) and the LVAR (dotted lines) the 68 percent posterior probability regions of the estimated impulses.

A number of observations are worth making. Overall, both VAR specifications give similar estimated impulse response functions. One difference worth noting is that, relative to the LVAR specification, the DVAR incorporates larger and more persistent effects on house prices and the GDP deflator. In what follows, we focus on the more precisely estimated LVAR specification. According to Figure 3, a one-standard-deviation housing demand shock leads to a persistent rise in real house prices of about 0.75 percent and an increase in the housing investment share of about 0.05 per-

\footnotetext{
4 For a discussion of VAR identification with sign restrictions, see,
} for example, Uhlig (2005). centage points. The effect on the overall economy is for real GDP to rise by about 0.10 percent after four quarters, whereas the effect on the GDP deflator takes longer (about three years) to peak at 0.08 percent above baseline. Note that, in the DVAR specification, the peak effect on goods prices is quite a bit larger. The monetary policy response as captured by the federal funds rate is initially limited, but eventually the federal funds rate increases by about 20 basis points after two years. The initial effect on the term spread is positive, reflecting that long-term interest rates rise in anticipation of inflation and a rise in shortterm rates.

To assess how reasonable these quantitative effects are, it is useful to compare them with other empirical results. One relevant literature is the empirical literature on the size of wealth/collateral effects of housing on consumption. As discussed in Muellbauer (2007) and Mishkin (2007), the empirical results are somewhat diverse, but some of the more robust findings suggest that the wealth effects from housing are approximately twice as large as those from stock prices. For example, Carroll, Otsuka, and Slacalek (2006) estimate that the long-run marginal propensity to consume out of a dollar increase in housing is 9 cents, compared with 4 cents for non-housing wealth. Similarly, using cross-country time series, Slacalek (2006) finds that it is 7 cents out of a dollar. Overall, the long-run marginal propensities to consume out of housing wealth range from 5 to 17 percent, but a reasonable median estimate is probably around 7 to 8 percent compared with a 5 percent elasticity for stock market wealth. How does this compare with the elasticities embedded in our estimated impulse response to a housing price shock? A 1 percent persistent increase in real house prices leads to a 0.075 percent increase in real consumption after four quarters. Taking into account that the housing wealth-to-consumption ratio is around 3 in the United States, this suggests a marginal propensity to consume about one-third of the long-run median estimate reported above. This lower effect on consumption may partly be explained by the fact that the increase in house prices is temporary. The mean elasticities embedded in the DVAR are somewhat lower. 


\section{Figure 3}

\section{Impulse Responses to a Housing Demand Shock, DVAR and LVAR}
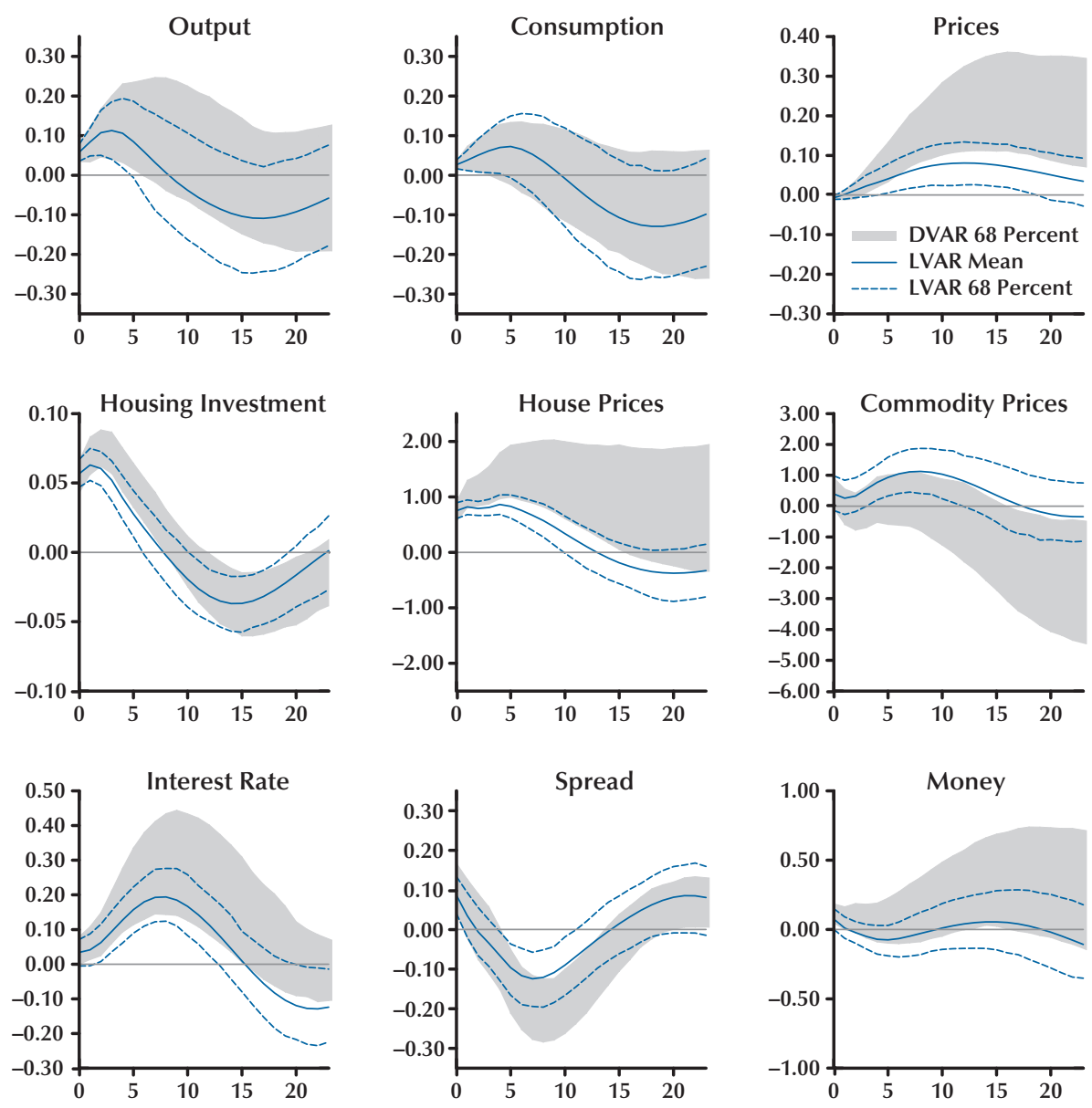

We can also compare our estimated impulse responses with simulations in Mishkin (2007) that use the Federal Reserve Bank U.S. (FRB/US) model. Mishkin (2007, Figure 5) reports that a 20 percent decline in real house prices under the estimated Taylor rule leads to a 1.5 percent deviation of real GDP from baseline in a version of the FRB/US with magnified channels, and to only a bit more than 0.5 percent in the benchmark version (which excludes an effect on real housing investment). Translating our results to a 20 percent real house price shock suggests a multiplier of 2.5 percent. This multiplier is quite a bit higher than that suggested by the FRB/US simulations, but in our case this may be partly the result of the strong immediate response of housing investment.

Finally, we can also compare the estimated impulse responses of Figure 3 with the impulse responses to a positive housing preference shock in the estimated structural DSGE model of the U.S. economy in Iacoviello and Neri (2007). They find that a 1 percent persistent increase in real house prices is associated with a 0.07 percent increase in consumption and a 3.6 percent increase in real housing investment. Whereas our estimated elasticity of real consumption is very similar, the elasticity of real housing investment 
Figure 4

Impulse Responses to a Monetary Policy Shock, DVAR and LVAR
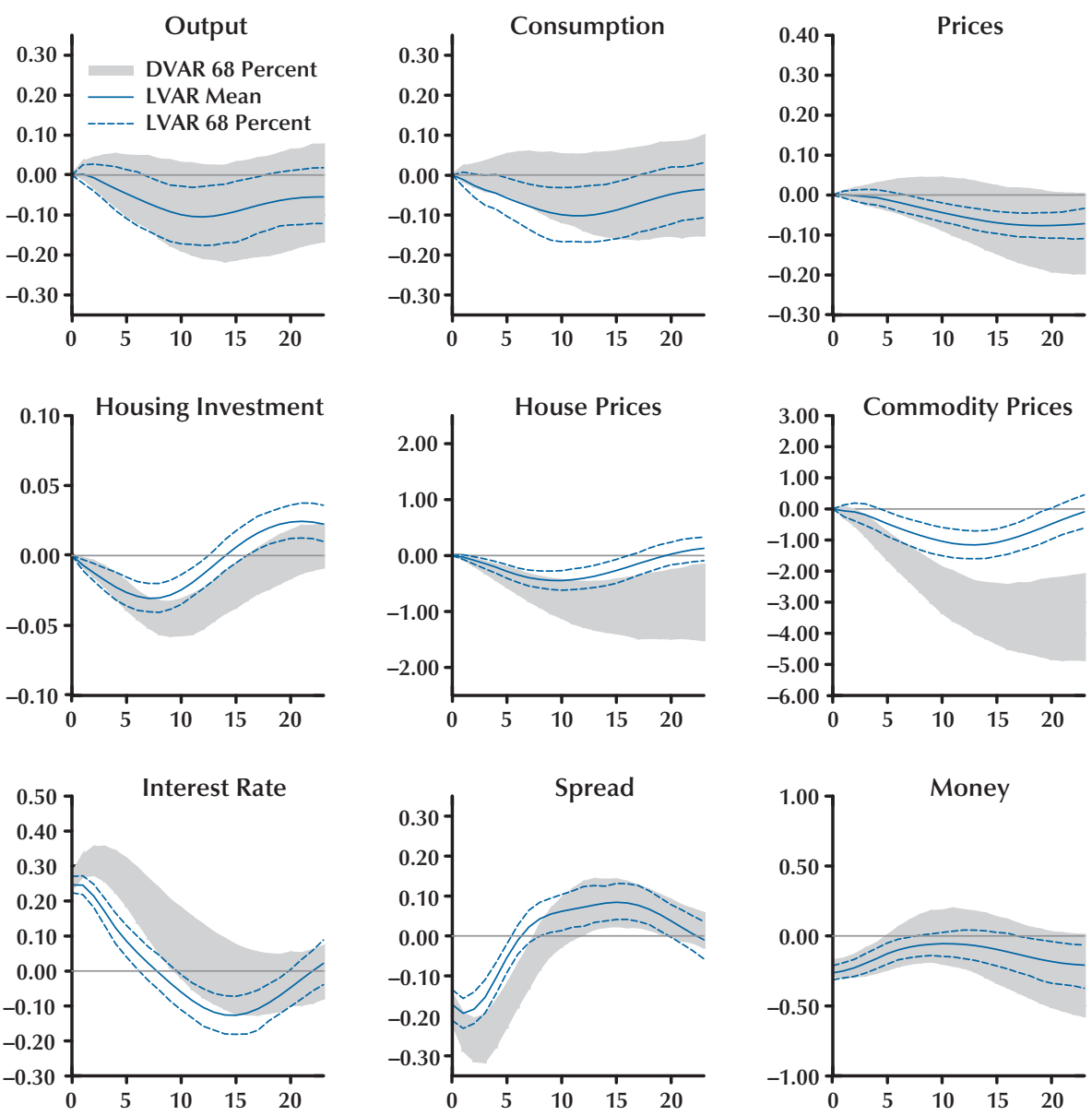

is quite a bit lower at approximately 1.5 percent. It falls at the lower bound of the findings of Topel and Rosen (1988), who estimate that, for every 1 percent increase in house prices lasting for two years, new construction increases on impact between 1.5 and 3.15 percent, depending on the specifications.

Turning to a monetary policy shock, the LVAR results in Figure 4 show that a persistent 25-basispoint tightening of the federal funds rate has the usual delayed negative effects on real GDP and the GDP deflator. The size of the real GDP response is quite small, with a maximum mean negative effect of about 0.1 percent deviation from base- line after three years. This effect is even smaller and less significant in the DVAR specification. For the LVAR specification, the effect on housing investment is larger and quicker, with a maximum negative effect of 0.03 percentage points of GDP (which would correspond to approximately 0.75 percent change) after about two years. Real house prices also immediately start falling and bottom out at 0.5 percent below baseline after two and a half years. The housing market effects are somewhat stronger in the DVAR specification. The higher sensitivity of housing investment to a monetary policy shock is consistent with the findings in the literature. For example, 


\section{Figure 5}

\section{Impulse Responses to a Term Spread Shock, DVAR and LVAR}
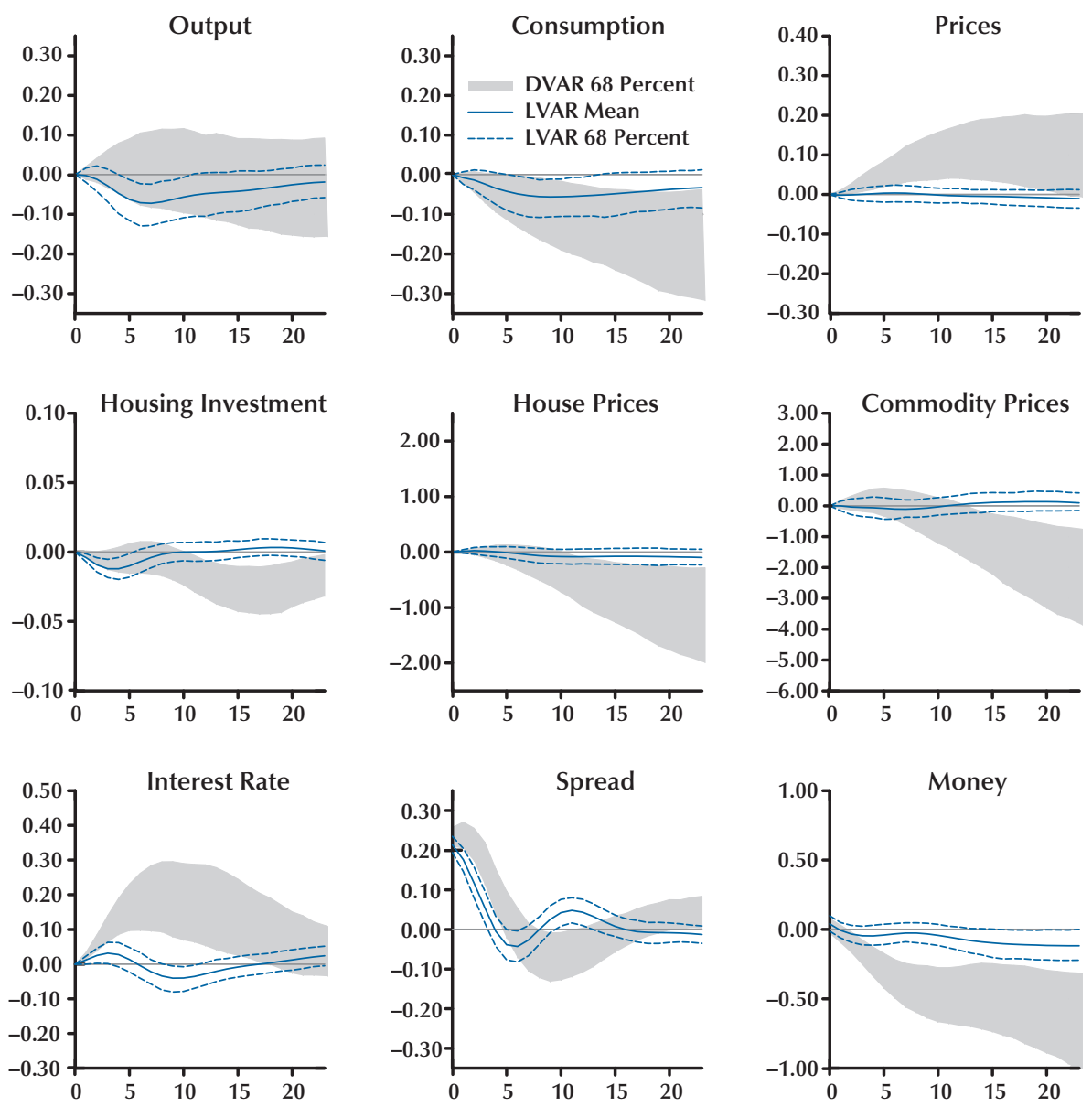

using identified VARs, Erceg and Levin (2002) find that housing investment is about 10 times as responsive as consumption to a monetary policy shock. Our results are also comparable with those reported in Mishkin (2007) using the FRB/US model. In those simulations, a 100-basis-point increase in the federal funds rate leads to a fall in real GDP of about 0.3 to 0.4 percent, although the lags (6 to 8 quarters) are somewhat smaller than those in our estimated BVARs. Further, the effect on real housing investment is faster (within a year) and larger, but the estimated magnitude of these effects (between 1 and 1.25 percent) is quite a bit larger in our case (around 2.5 percent).
Dynan, Elmendorf, and Sichel (2005) argue that the interest rate sensitivity of real housing investment has fallen since the second half of the 1980s (partly the result of deregulation of the mortgage market in the early 1980s). Our results suggest elasticities that are more in line with Erceg and Levin (2002) than with the FRB/US simulations.

Our results can also be compared with the impulse responses to an adverse interest rate shock in Iacoviello and Neri (2007). They find that a 50-basis-point temporary increase in the federal funds rate leads to a fall in real house prices of about 0.75 percent from baseline, compared with a delayed 1 percent fall in real house 
Table 2A

Shares of Housing Demand, Monetary Policy, and Term Spread Shocks in Variance Decompositions, DVAR

\begin{tabular}{|c|c|c|c|c|c|}
\hline \multirow[b]{2}{*}{ Variable } & \multirow[b]{2}{*}{ Shock } & \multicolumn{4}{|c|}{ Horizon } \\
\hline & & 0 & 3 & 11 & 23 \\
\hline \multirow[t]{3}{*}{ Output } & Housing & 0.016 & 0.034 & 0.052 & 0.062 \\
\hline & Monetary policy & 0.000 & 0.004 & 0.021 & 0.039 \\
\hline & Term premium & 0.000 & 0.003 & 0.015 & 0.028 \\
\hline \multirow[t]{3}{*}{ Consumption } & Housing & 0.005 & 0.018 & 0.033 & 0.055 \\
\hline & Monetary policy & 0.000 & 0.003 & 0.015 & 0.029 \\
\hline & Term premium & 0.000 & 0.005 & 0.034 & 0.063 \\
\hline \multirow[t]{3}{*}{ Prices } & Housing & 0.002 & 0.013 & 0.120 & 0.166 \\
\hline & Monetary policy & 0.000 & 0.003 & 0.014 & 0.037 \\
\hline & Term premium & 0.000 & 0.006 & 0.034 & 0.046 \\
\hline \multirow[t]{3}{*}{ Housing investment } & Housing & 0.521 & 0.579 & 0.382 & 0.291 \\
\hline & Monetary policy & 0.000 & 0.015 & 0.175 & 0.136 \\
\hline & Term premium & 0.000 & 0.005 & 0.023 & 0.062 \\
\hline \multirow[t]{3}{*}{ House prices } & Housing & 0.535 & 0.554 & 0.410 & 0.242 \\
\hline & Monetary policy & 0.000 & 0.010 & 0.068 & 0.083 \\
\hline & Term premium & 0.000 & 0.002 & 0.021 & 0.060 \\
\hline \multirow[t]{3}{*}{ Commodity prices } & Housing & 0.027 & 0.028 & 0.041 & 0.085 \\
\hline & Monetary Policy & 0.000 & 0.012 & 0.167 & 0.222 \\
\hline & Term premium & 0.000 & 0.004 & 0.018 & 0.055 \\
\hline \multirow[t]{3}{*}{ Interest rate } & Housing & 0.037 & 0.061 & 0.165 & 0.178 \\
\hline & Monetary policy & 0.752 & 0.496 & 0.192 & 0.166 \\
\hline & Term premium & 0.000 & 0.023 & 0.076 & 0.088 \\
\hline \multirow[t]{3}{*}{ Spread } & Housing & 0.090 & 0.050 & 0.177 & 0.186 \\
\hline & Monetary policy & 0.223 & 0.303 & 0.214 & 0.206 \\
\hline & Term premium & 0.336 & 0.245 & 0.146 & 0.134 \\
\hline \multirow[t]{3}{*}{ Money } & Housing & 0.060 & 0.044 & 0.062 & 0.099 \\
\hline & Monetary policy & 0.204 & 0.141 & 0.044 & 0.045 \\
\hline & Term premium & 0.013 & 0.042 & 0.129 & 0.135 \\
\hline
\end{tabular}

NOTE: The reported shares are averages over the posterior distribution and relate to the (log) level variables. 


\section{Table 2B}

Shares of Housing Demand, Monetary Policy, and Term Spread Shocks in Variance Decompositions, LVAR

\begin{tabular}{|c|c|c|c|c|c|}
\hline \multirow[b]{2}{*}{ Variable } & \multirow[b]{2}{*}{ Shock } & \multicolumn{4}{|c|}{ Horizon } \\
\hline & & 0 & 3 & 11 & 23 \\
\hline \multirow[t]{3}{*}{ Output } & Housing & 0.019 & 0.049 & 0.073 & 0.106 \\
\hline & Monetary policy & 0.000 & 0.005 & 0.036 & 0.052 \\
\hline & Term premium & 0.000 & 0.005 & 0.026 & 0.026 \\
\hline \multirow[t]{3}{*}{ Consumption } & Housing & 0.005 & 0.021 & 0.051 & 0.093 \\
\hline & Monetary policy & 0.000 & 0.008 & 0.040 & 0.051 \\
\hline & Term premium & 0.000 & 0.005 & 0.021 & 0.024 \\
\hline \multirow[t]{3}{*}{ Prices } & Housing & 0.002 & 0.017 & 0.127 & 0.153 \\
\hline & Monetary policy & 0.000 & 0.005 & 0.038 & 0.114 \\
\hline & Term premium & 0.000 & 0.005 & 0.012 & 0.016 \\
\hline \multirow[t]{3}{*}{ Housing investment } & Housing & 0.582 & 0.554 & 0.357 & 0.351 \\
\hline & Monetary policy & 0.000 & 0.027 & 0.124 & 0.125 \\
\hline & Term premium & 0.000 & 0.015 & 0.021 & 0.019 \\
\hline \multirow[t]{3}{*}{ House prices } & Housing & 0.586 & 0.610 & 0.360 & 0.229 \\
\hline & Monetary policy & 0.000 & 0.011 & 0.087 & 0.066 \\
\hline & Term premium & 0.000 & 0.003 & 0.010 & 0.014 \\
\hline \multirow[t]{3}{*}{ Commodity prices } & Housing & 0.030 & 0.044 & 0.154 & 0.149 \\
\hline & Monetary policy & 0.000 & 0.008 & 0.072 & 0.100 \\
\hline & Term premium & 0.000 & 0.005 & 0.012 & 0.015 \\
\hline \multirow[t]{3}{*}{ Interest rate } & Housing & 0.032 & 0.055 & 0.217 & 0.211 \\
\hline & Monetary policy & 0.709 & 0.453 & 0.206 & 0.177 \\
\hline & Term premium & 0.000 & 0.007 & 0.018 & 0.018 \\
\hline \multirow[t]{3}{*}{ Spread } & Housing & 0.072 & 0.048 & 0.129 & 0.150 \\
\hline & Monetary policy & 0.230 & 0.281 & 0.163 & 0.152 \\
\hline & Term premium & 0.355 & 0.215 & 0.114 & 0.085 \\
\hline \multirow[t]{3}{*}{ Money } & Housing & 0.040 & 0.036 & 0.053 & 0.066 \\
\hline & Monetary policy & 0.257 & 0.237 & 0.089 & 0.060 \\
\hline & Term premium & 0.015 & 0.020 & 0.021 & 0.025 \\
\hline
\end{tabular}

NOTE: The reported shares are averages over the posterior distribution and relate to the (log) level variables. 
Figure 6A, Panel 1

\section{Counterfactuals, Shutting Down Each of the Identified Shocks, DVAR}
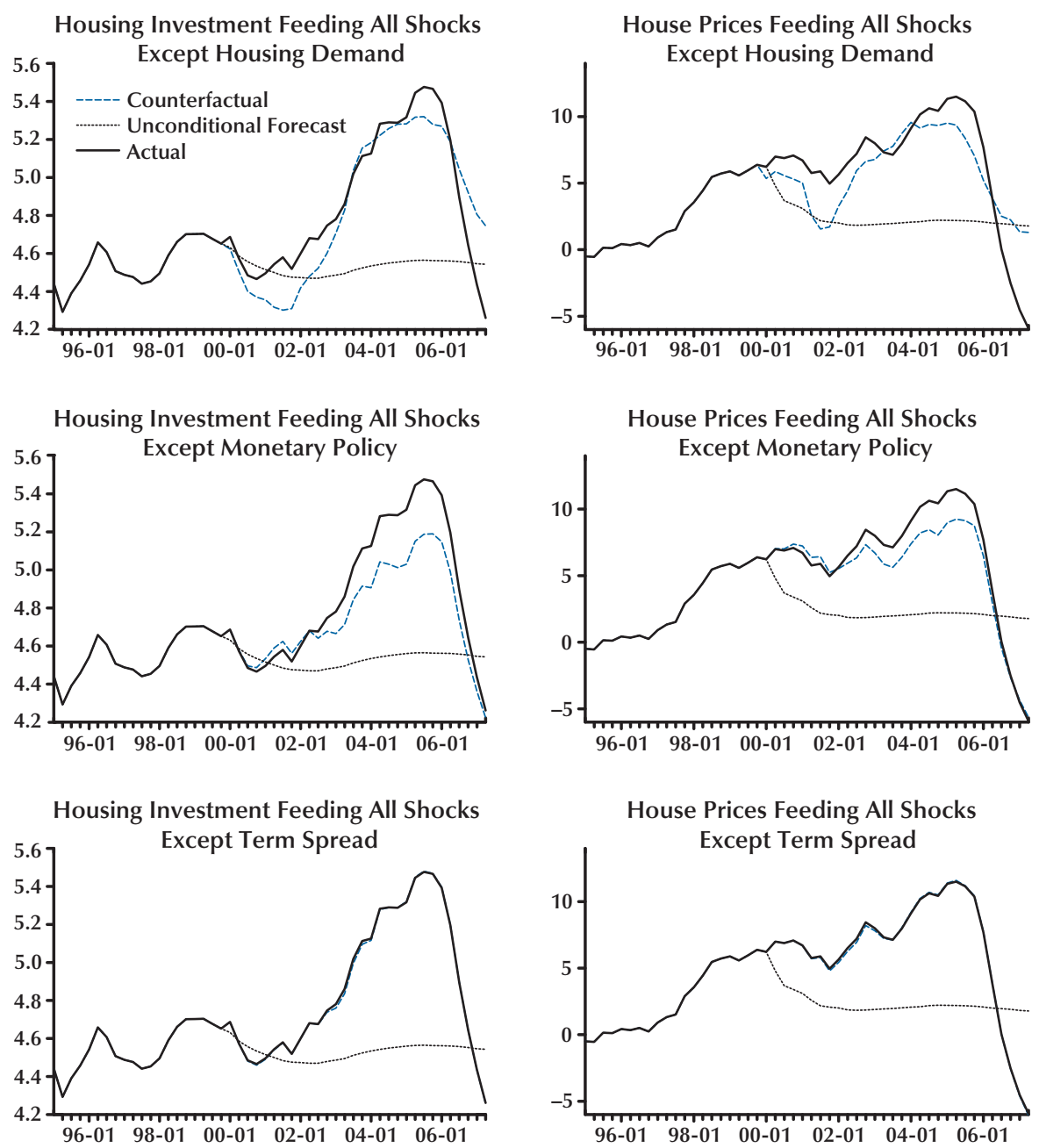

prices in our case (the delay is partly the result of our recursive identification assumption). According to the estimates of Iacoviello and Neri (2007), real investment responds six times more strongly than real consumption and two times more strongly than real fixed investment. Overall, this is consistent with our results. However, the effects in Iacoviello and Neri (2007) are immediate, whereas they are delayed in our case. (See also Del Negro and Otrok, 2007.)

In conclusion, the overall quantitative estimates of the effects of a monetary policy shock are in line with those found in the empirical literature. Similarly to our results, Goodhart and Hofmann (2007) find that a one-standard-deviation shock to the real short-term interest rate has about the same quantitative effect on the output gap as a one-standard-deviation shock to the real house price gap.

Finally, in the light of the discussion of the effects of developments in long-term interest rates on the house price boom and bust in the United States and many other countries, it is also interesting to look at the effects of a term spread shock 


\section{Figure 6A, Panel 2}

\section{Counterfactuals, Shutting Down Each of the Identified Shocks, DVAR}

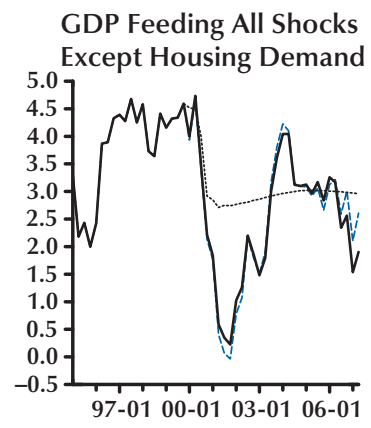

GDP Feeding All Shocks Except Monetary Policy

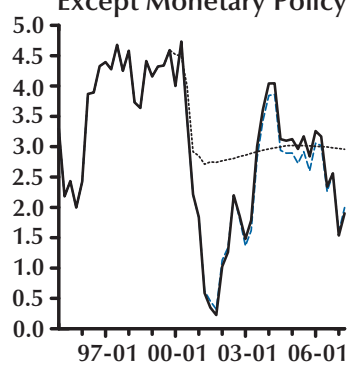

GDP Feeding All Shocks

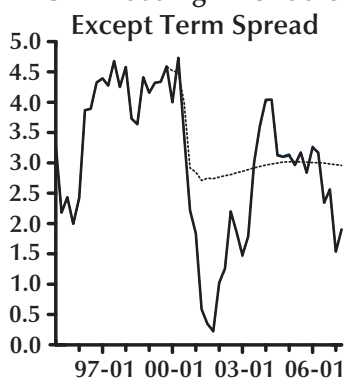

Prices Feeding All Shocks Except Housing Demand

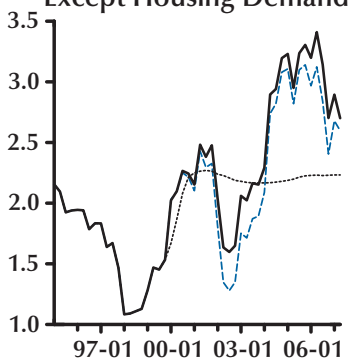

Prices Feeding All Shocks

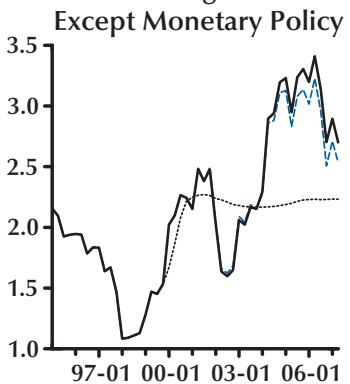

Prices Feeding All Shocks

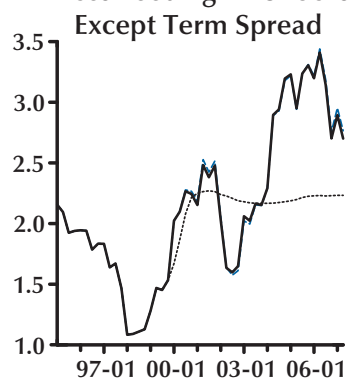

Interest Rate Feeding All Shocks

Except Housing Demand

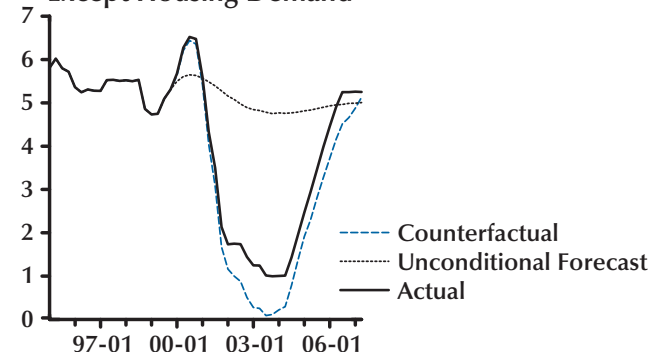

Interest Rate Feeding All Shocks

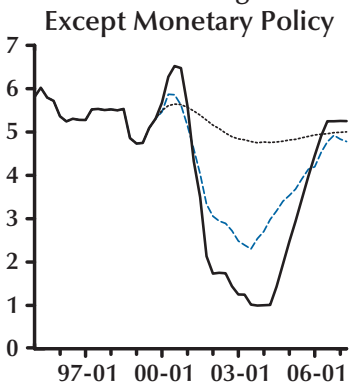

Interest Rate Feeding All Shocks

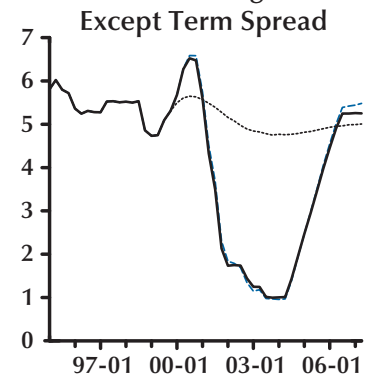

on the housing market. Figure 5 shows that a 20basis-point increase in long-term interest rates over the federal funds rate has a quite significant effect on housing investment, which drops by more than 0.014 percentage points of GDP (which corresponds to a 0.3 percent change) after about a year. Also, real GDP falls with a bit more of a delay, by about 0.075 percent after six quarters. Both the GDP deflator and real house prices fall, but only gradually. Overall, the size of the impulse responses is, however, small.
Tables 2A and 2B report the contribution of the three shocks to the forecast-error variance at different horizons in both specifications. Overall, the housing demand, monetary policy, and term spread shocks account for only a small fraction of the total variance in real GDP and in the GDP deflator. Monetary policy and housing demand shocks do, however, account for a significant fraction of the variance in the housing market.

This can be verified by looking at the contribution of the three shocks to the historical boom and bust episode since 2000, as depicted in 
Figure 6B, Panel 1

\section{Counterfactuals, Shutting Down Each of the Identified Shocks, LVAR}
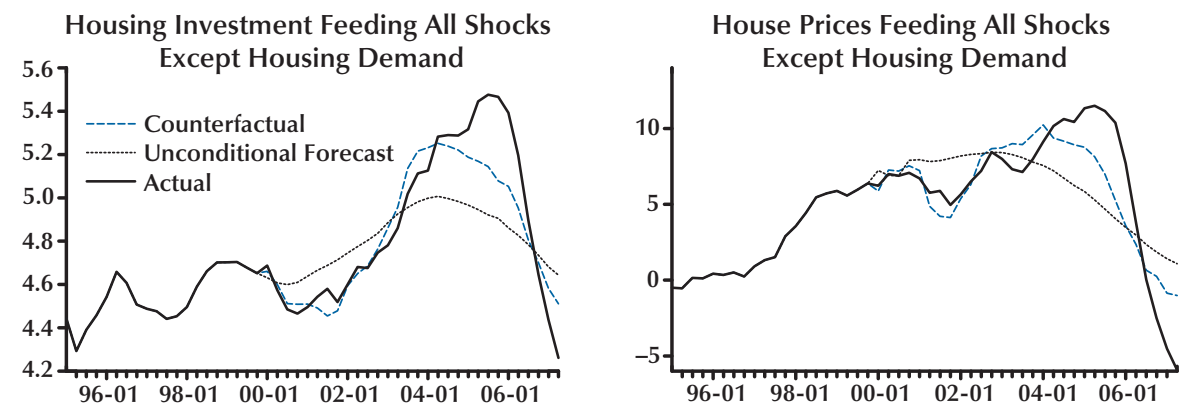

Housing Investment Feeding All Shocks
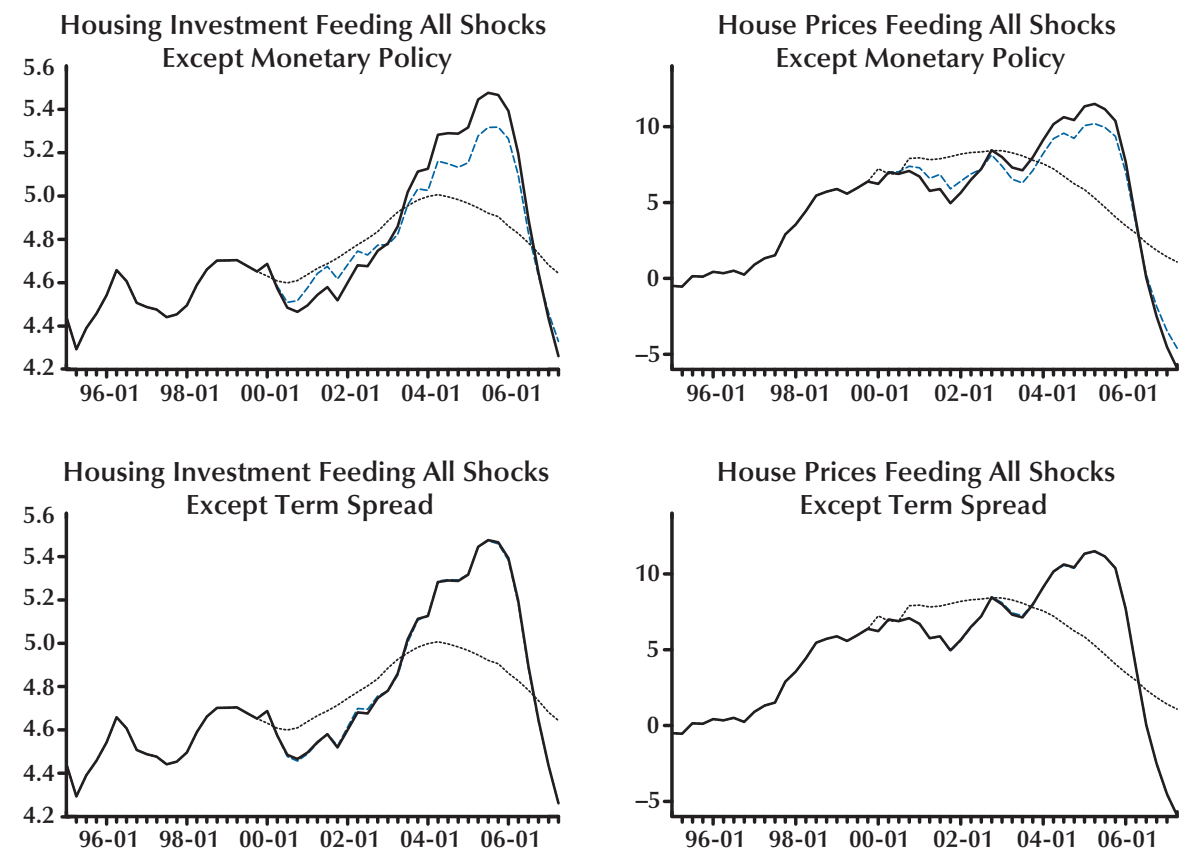

Figure 6A for the DVAR and 6B for the LVAR. Panel 1 of each figure shows the developments of the real housing investment-to-GDP ratio (first column) and the annual change in real house prices (second column). Panel 2 of each figure shows output (first column), prices (second column), and interest rates (third column). Each graph includes the actual data (black lines), unconditional forecasts as of 2000 (black dotted lines), and the counterfactual evolution (blue dashed lines) when each of the following three identified shocks are put to zero: a housing demand shock (first row), monetary policy shock (second row), and term spread shock (third row).

For the DVAR (Figure 6A), the term spread shock does not have a visible effect on the housing market or the economy as a whole. The housing demand shock has a large positive effect on the housing market in 2001 and 2002 and again in 2004 and 2005. A negative demand shock also explains a large fraction of the fall in construction and house price growth from 2006 onward. These shocks have only negligible effects on overall GDP growth, but do seem to have pushed up inflation 
Figure 6B, Panel 2

\section{Counterfactuals, Shutting Down Each of the Identified Shocks, LVAR}
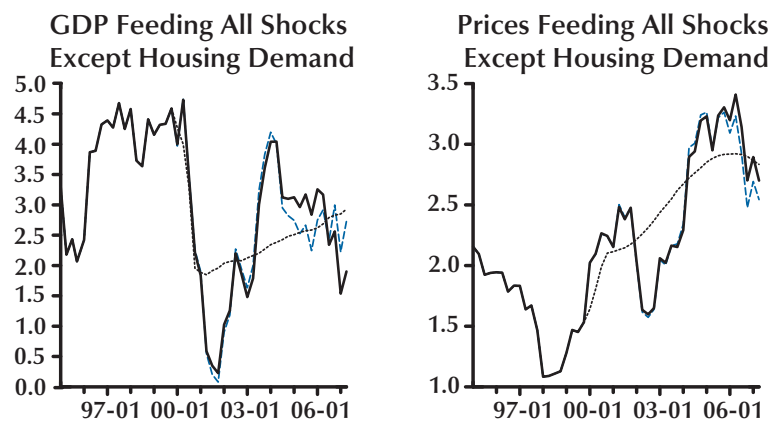

Interest Rate Feeding All Shocks

GDP Feeding All Shocks Except Monetary Policy

Prices Feeding All Shocks

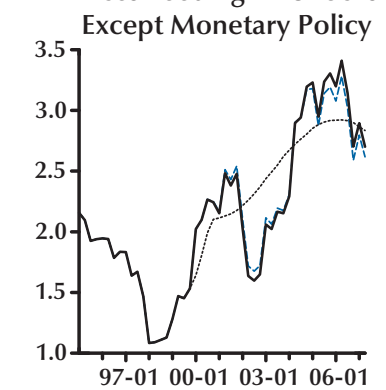

Except Housing Demand
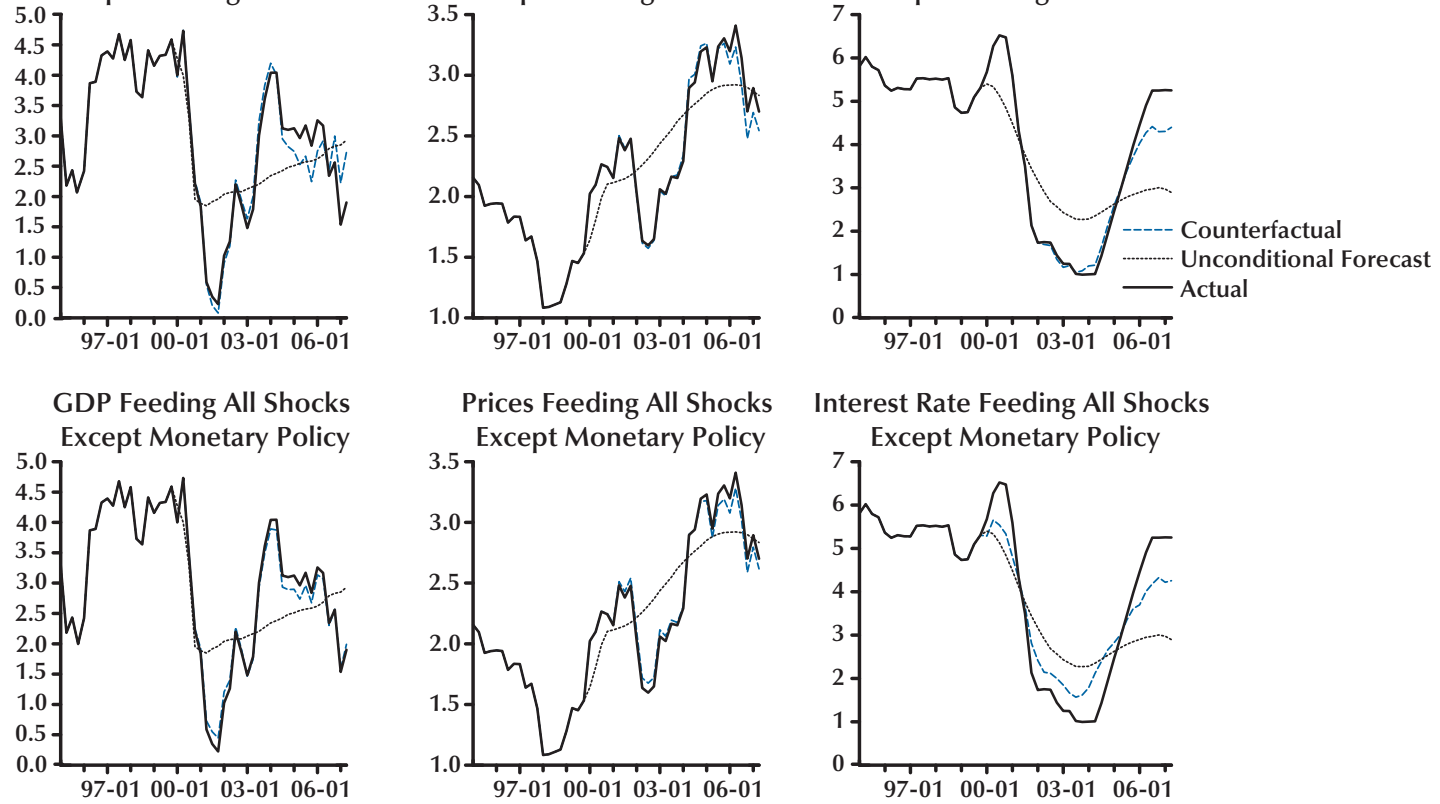

GDP Feeding All Shocks
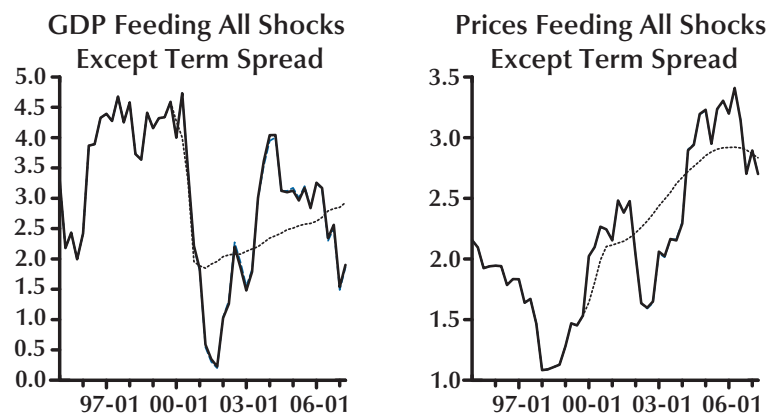

Interest Rate Feeding All Shocks

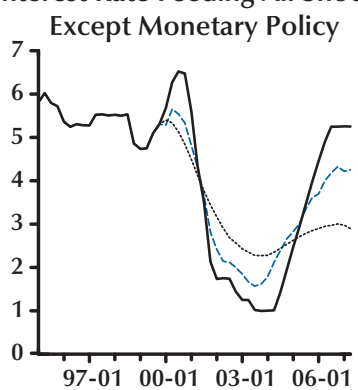

Interest Rate Feeding All Shocks

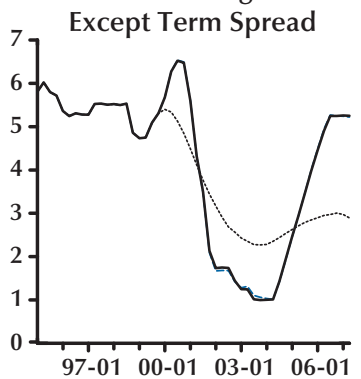

by 10 to 20 basis points over most of the post-2000 period. Loose monetary policy also seems to have contributed to the housing boom in 2004 and 2005. Without the relatively easy policy of late 2003 and early 2004, the boom in house price growth would have stayed well below the 10 percent growth rate in 2005. Easy monetary policy also has a noticeable, though small effect, on GDP growth and inflation.

The LVAR results depicted in Figure 6B give similar indications, although they generally attribute an even larger role to the housing demand shocks.

\section{HOUSE PRICES AND THE MONETARY POLICY STANCE IN THE UNITED STATES}

The idea of measuring monetary conditions by taking an appropriate weight of interest rates and asset prices was pioneered by the Bank of Canada and the Reserve Bank of New Zealand in the 1990s. Because both countries are small open economies, these central banks worried about how changes in the value of the exchange rate 
may affect the monetary policy stance. ${ }^{5}$ The idea was to construct a weighted index of the shortterm interest rate and the exchange rate, where the weights reflected the relative effect of the exchange rate on an intermediate or final target variable, such as the output gap, output growth, or inflation. A number of authors have extended the idea of the MCI to other asset prices, arguing that those asset prices may be equally or more important than the exchange rate. One prominent example is Goodhart and Hofmann (2007), who argue that real house prices should receive a significant weight in an MCI because of their significant effect on the economy. For the United States, they argue that the relative weight of the short-term interest rate versus house prices should be of the order of 0.6 to 1.8 .

In the small literature that developed following the introduction of the MCI concept, a number of shortcomings have been highlighted. ${ }^{6}$ One difficulty is that the lag structure of the effects of changes in the interest rate and real house prices on the economy may be different. As noted above, according to our estimates, the effect of an interest rate shock on economic activity appears to take somewhat longer than the effect of a house price shock. In response, Batini and Turnbull (2002;BT) proposed a dynamic MCI that takes into account the different lag structures by weighting all current and past interest rates and asset prices with their estimated impulse responses. Another shortcoming of the standard MCI is that it is very difficult to interpret the MCI as an indicator of the monetary policy stance, because it does not take into account that changes in monetary conditions will typically be endogenous to the state of the economy. The implicit assumption of the standard MCI is that the monetary conditions are driven by exogenous shocks. This is clearly at odds with the identified VAR literature that suggests that most of the movements in monetary conditions are in response to the state of the economy. For example, changes in the federal funds rate will

\footnotetext{
5 See, for example, Freedman (1994 and 1995a,b) and Duguay (1994).

${ }^{6}$ See, for example, Gerlach and Smets (2000).
}

be typically in response to changing economic conditions and a changing outlook for price stability. An alternative way of expressing this drawback is that the implicit benchmark against which the MCI is measured does not depend on the likely source of the shocks in the economy. As a result, the benchmark in the standard MCI does not depend on the state of the economy, although clearly for given objectives the optimal MCI will vary with the shocks to the economy. A third shortcoming is that often the construction of an MCI does not take into account that the estimated weight of its various components is subject to uncertainty and estimation error. This uncertainty needs to be taken into account when interpreting the significance of apparent changes in monetary conditions. The methodology developed by Céspedes et al. (CLMM; 2006) addresses each of these shortcomings.

In this section, we apply a version of the MCI proposed by CLMM to derive a measure of the monetary policy stance that takes into account movements in the short- and long-term interest rates and in real house prices. Using this index, we try to answer this question: Did the rise in house prices and the fall in long-term interest rates since 2000 lead to an implicit easing of monetary policy in the United States? We use the BVARs estimated in the previous section to implement the methodology. In the next subsection, we define the MCI and use a simple analytical example to illustrate its logic. Next, we apply it to the U.S. economy using the estimated BVARs.

\section{An MCI in a VAR: Methodology and Inturition}

For the sake of example, let the economy be described by a stationary VAR of order one:

$$
\left[\begin{array}{l}
X_{t} \\
P_{t}
\end{array}\right]=\left[\begin{array}{ll}
A_{11} & A_{12} \\
A_{21} & A_{22}
\end{array}\right]\left[\begin{array}{c}
X_{t-1} \\
P_{t-1}
\end{array}\right]+\left[\begin{array}{l}
B_{1} \\
B_{2}
\end{array}\right] \varepsilon_{t},
$$

where $X_{t}$ is the vector of nonpolicy variables, such as output and inflation, and $P_{t}$ is the vector of monetary policy and financial variables, which in our case are the short-term interest rate, the long-term interest rate spread, and the real house 
price index. As in BT, a standard dynamic MCI with respect to a target variable $j$ can then be defined as

$$
M C I_{B T, t}^{j}=S_{j} \sum_{s=1}^{H} A_{11}^{s-1} A_{12}\left(P_{t-s}-P_{t-s}^{*}\right),
$$

where $S_{j}$ is a selection vector that selects the target variable $j$ from the list of non-policy variables. Typically, the target variable in the construction of an MCI is either output growth or the output gap. This is based on the notion that financial and monetary conditions affect inflation primarily through their effect on spending and output. However, inflation can be used as a target variable also. In this paper, we will present results for both output growth and inflation as target variables. The parameter $H$ is the time period over which lags of the monetary conditions are considered. $P_{t-s}^{*}$ is typically given by the steady state of the monetary conditions. In our case, this would be the equilibrium nominal interest rate, the steady-state term spread, and steady-state real house price growth rate. Alternatively, it could also be given by the monetary conditions that would have been expected as of period $t-H$, if there had been no shocks from period $t-H$ to $t$. Equation (2) illustrates that the standard MCI is a weighted average of the deviations of current and past policy variables from their steady-state values, where the weights are determined by the partial elasticity of output with respect to a change in the policy variable.

As discussed above, a problem with this notion of the MCI is that the policy variables are treated as exogenous and independent from the underlying economic conditions, or, alternatively, they are assumed to be driven by exogenous shocks. As a result, it is very problematic to interpret this index as a measure of the monetary policy stance. For example, it may easily be the case that the policy rate rises above its steadystate value because of positive demand shocks. In this case, monetary policy may either be too loose, neutral, or too tight, depending on whether the higher interest rate is able to offset the effect of the demand shocks only partially, fully, or more than fully. Instead, the standard MCI will always indicate that monetary conditions have tightened.

In contrast to the standard MCI, the alternative MCI proposed by CLMM does take into account the endogeneity of the policy instruments. In this case the MCI is defined as

(5)

$$
\begin{aligned}
& M C I_{C L M M, t}^{j}=S_{j} \sum_{s=1}^{H} A_{11}^{s-1} A_{12}\left(P_{t-s}-P_{t-s}^{*}\right) \\
& +S_{j} \sum_{s=1}^{H} A_{11}^{s-1} B_{1}\left(E\left[\varepsilon_{t-s} \mid P\right]-E\left[\varepsilon_{t-s} \mid P^{*}\right]\right) .
\end{aligned}
$$

The first part is the same as in the standard case (equation (4)), but the second part adds the effect of shocks that are most consistent with the observed path of monetary conditions. More specifically, the shocks are drawn from their distribution, subject to the restriction that they generate the observed path of monetary conditions. Doan et al. (1984) and Waggoner and Zha (1999) show that the mean of this constrained distribution is given by

$$
\varepsilon_{\text {stacked }}=R^{\prime}\left(R R^{\prime}\right)^{-1}(P-E[P])_{\text {stacked }},
$$

where $\varepsilon_{\text {stacked }}^{P}$ is a vector of stacked shocks over period $H, R$ is a stacked matrix of impulse response coefficients of the monetary conditions with respect to the shocks, and $P-E[P]$ is the vector of correspondingly stacked forecast errors associated with the observed or assumed monetary conditions over the same period $H$.

To understand the intuition for why the MCI by CLMM is a potentially much better indicator of the stance of monetary policy, it is useful to go through a simple static analytical example.

Assume the economy is given by the following set of equations:

$$
\begin{gathered}
y_{t}=\alpha_{1} s_{t}+\alpha_{2} h_{t}+\varepsilon_{t}^{y} \\
s_{t}=\beta_{1} \varepsilon_{t}^{y}+\beta_{2} \varepsilon_{t}^{h}+\beta_{3} \varepsilon_{t}^{s} \\
h_{t}=\delta s_{t}+\varepsilon_{t}^{h},
\end{gathered}
$$

where $y_{t}$ is the target variable, say, output growth, $s_{t}$, is the short-term policy rate, $h_{t}$ is real house prices, and there are three shocks: an output shock, 
a policy shock, and a housing shock. Equation (7) reflects the dependence of output on the monetary conditions and an output shock. For convenience, we have in this case assumed that there are no lags in the transmission process. Equation (8) is a monetary policy reaction function, and equation (9) shows how house prices depend on the short rate and a shock.

In this case, the standard MCI (as in BT) is given by

$$
M C I_{B T, t}=\alpha_{1} s_{t}+\alpha_{2} h_{t}
$$

and is independent of the monetary policy reaction function. If $\alpha_{1}$ is negative and $\alpha_{2}$ is positive, a rise in house prices will lead to an easing of monetary conditions unless the short-term interest rate rises to exactly offset the effect of house prices on the target variable.

In contrast, the MCI of CLMM is given by

$$
M C I_{C L M M, t}=\alpha_{1} s_{t}+\alpha_{2} h_{t}+E\left[\varepsilon_{t}^{y} \mid s_{t}, h_{t}\right]
$$

where we have assumed that all variables are measured as deviations from the steady state. As in equation (6), the mean output shock needs to be consistent with the observed short-term interest rate and real house prices.

Next, we derive that the expression of the last term in equation (11) is a function of the interest rate and house prices. From equations (6) and (7), it is clear that the relation between the interest rate conditions and the shocks is given by

$$
\left[\begin{array}{l}
s_{t} \\
h_{t}
\end{array}\right]=\left[\begin{array}{ccc}
\beta_{1} & \beta_{2} & \beta_{3} \\
\delta \beta_{1} & 1+\delta \beta_{2} & \delta \beta_{3}
\end{array}\right]\left[\begin{array}{c}
\varepsilon_{t}^{y} \\
\varepsilon_{t}^{h} \\
\varepsilon_{t}^{s}
\end{array}\right]=R \varepsilon_{t} .
$$

As discussed above, given a joint standard normal distribution of the shocks, the mean of the shocks conditional on the observed interest rates is given by

$$
E\left[\varepsilon_{t} \mid s_{t}, h_{t}\right]=R^{\prime}\left(R R^{\prime}\right)^{-1}\left[\begin{array}{l}
s_{t} \\
h_{t}
\end{array}\right],
$$

where $R$ is given in equation (12).

To simplify even further, assume that $\beta_{3}=0$, that is, there is no policy shock. In this case, there is a one-to-one relationship between the shocks and the observed interest rate and house prices, given by

$$
\left[\begin{array}{c}
\varepsilon_{t}^{y} \\
\varepsilon_{t}^{h}
\end{array}\right]=\left[\begin{array}{cc}
\left(1+\delta \beta_{2}\right) / \beta_{1} & -\beta_{2} / \beta_{1} \\
-\delta & 1
\end{array}\right]\left[\begin{array}{l}
s_{t} \\
h_{t}
\end{array}\right] .
$$

As a result, the MCI of CLMM is given by

$$
\begin{aligned}
& M C I_{C L M M, t}= \\
& \left(\alpha_{1}+\left(1+\delta \beta_{2}\right) / \beta_{1}\right) s_{t}+\left(\alpha_{2}-\beta_{2} / \beta_{1}\right) h_{t} .
\end{aligned}
$$

Comparing expressions (15) and (10), it is obvious that the MCIs of BT and CLMM have different weights on the short-term interest rate and house prices. The weights in the MCI of CLMM depend not only on the partial elasticities of output with respect to the short-term interest rate and house prices, but also on the coefficients in the policy reaction function and the elasticity of house prices with respect to the short-term interest rate.

To see why the MCI of CLMM is a better indicator of the monetary policy stance, it is useful to investigate how the weights in (15) will depend on systematic policy behavior. From equations (7) and (9), one can easily show that, if the central bank targets output growth, the optimal interest rate reaction function is given by

$$
s_{t}=-\frac{1}{\alpha_{1}+\delta \alpha_{2}} \varepsilon_{t}^{y}-\frac{\alpha_{2}}{\alpha_{1}+\delta \alpha_{2}} \varepsilon_{t}^{h} .
$$

If the interest rate elasticity of output is negative $\left(\alpha_{1}<0\right)$ and elasticity with respect to house prices is positive $\left(\alpha_{2}<0\right)$, then a central bank trying to stabilize output will lean against positive output and house price shocks, where the size of the reaction coefficient will depend on the strength and the channels of the transmission mechanism.

Substituting the coefficients $\beta_{1}$ and $\beta_{2}$ in (15) with the coefficients in expression (16), it can be verified that the MCI of CLMM will be equal to zero. In other words, a policy that stabilizes output will be seen as a neutral policy according to this index. In contrast, it is obvious that such a 
change in the policy reaction function will not affect the standard MCI.

Instead, assume that the central bank reacts optimally to the output shock, as in equation (13), but does not respond to the shock to house prices $\left(\beta_{2}=0\right)$. In this case, it can be shown that the MCI of CLMM is given by

$$
M C I_{C L M M, t}=\alpha_{2}\left(h_{t}-\delta s_{t}\right)=\alpha_{2} \varepsilon_{t}^{h} .
$$

This result is very intuitive: When the central bank does not respond to house price shocks and a rise in house prices has a stimulative effect on output, the MCI of CLMM will indicate easy monetary conditions whenever there is a positive shock to house prices.

This simple example makes it clear that, in order to have a meaningful indicator of the monetary policy stance, it is important to realize that the monetary conditions endogenously reflect all shocks that hit the economy.

\section{An Application to House Prices and the Policy Stance in the United States}

Obviously, the static example is too simple to bring to the data. In reality, monetary conditions will have lagged effects on output and inflation and the lag patterns may differ across the various components, as shown earlier. In this section, we use the two specifications of the BVAR—the LVAR and the DVAR—-to calculate MCIs for the U.S. economy. Consistent with the MCI literature, we use real GDP growth and inflation as the target variables. Moreover, to take into account the lags in the transmission process of monetary policy that we documented in the third section, we assume that real GDP growth is expected annual GDP growth one year ahead, whereas inflation is expected annual inflation two years ahead. Figures 7A and 7B show the results of this exercise. To illustrate the effect of taking endogeneity of the indicators of stance into account, we also compare the MCI of CLMM (which incorporates the full set of shocks) with the MCI of BT. In the latter case, we assume that the observed interest rates and house prices are driven by only the three exogenous shocks identified in the third section.
Figure 7A shows for the DVAR and 7B for the LVAR the estimated 68 percent probability regions for the MCI of CLMM (blue dotted lines) and the MCI of BT (gray shaded areas) based on one-year-ahead annual output growth (left column) and two-year-ahead annual inflation (right column) using the following indicators of monetary conditions: the federal funds rate (first row); the federal funds rate and the term spread (second row); and the federal funds rate, the term spread, and real house prices (third row). The MCIs shown are basically the difference between the conditional forecast of the target variable based on the actual path of the chosen indicators of stance and the unconditional forecast of the target variable.

A few observations are worth making on the basis of Figure 7A. First, overall, the MCI with expected output growth as a target variable and the MCI with inflation as the target variable give similar indications about stance. Financial conditions were relatively tight in 2000-01, then gradually became relatively loose in 2002-05 before turning tight again during 2006. Second, the uncertainty surrounding the MCIs is very high. Based on standard significance levels, the monetary conditions were not significantly different from neutral during the whole period. Third, taking house prices into account (third row of Figure 7A) does seem to matter for measuring the monetary policy stance. More specifically, buoyant growth in house prices in 2004 and 2005 suggests that monetary policy was relatively loose in this period, whereas it turned tight in 2007. During the housing boom, easy monetary conditions implied two-year-ahead annual inflation that was more than 0.5 percentage points above its steady state. Most recently, tight conditions imply expected inflation almost 0.5 percentage points below the target. These results differ marginally when the LVAR specification is used (compare Figure 7B with 7A).

In Figure 7B, a comparison of the 68 percent posterior probability regions for the MCI of CLMM (blue dotted lines) with those for the MCI of BT (shaded areas) reveals that, although the broad messages of the estimated MCIs are similar, conditioning on the three identified exogenous shocks 
Figure 7A

MCIs of CLMM and BT, DVAR
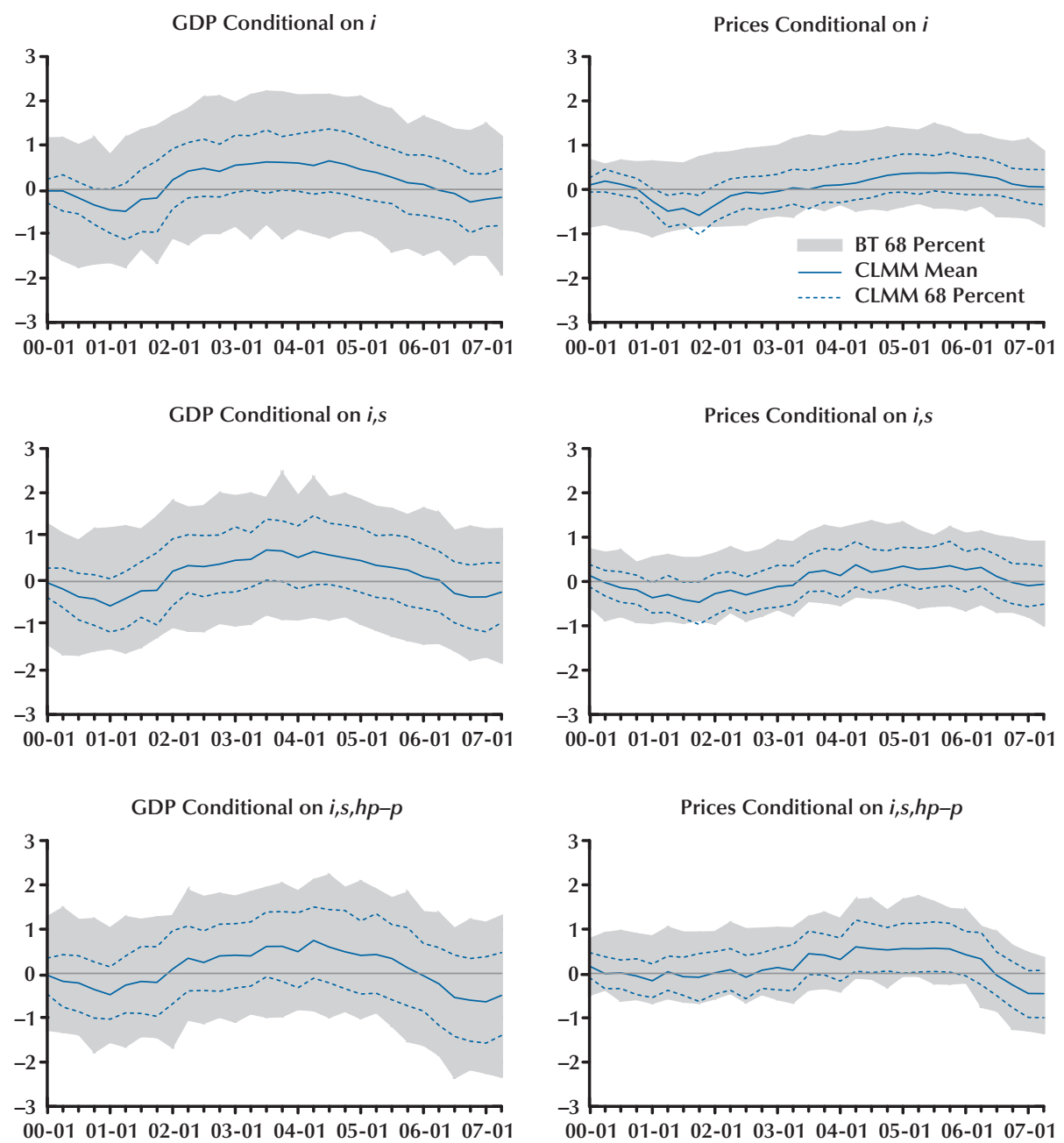

only (the MCI of BT) gives less-precise estimates. This is partly because these exogenous shocks contribute only to a limited degree to the forecast variance of output and inflation. As a result, the effects are also less precisely estimated. The point estimates are similar, which suggests that the developments in 2002-05 were strongly influenced by the policy and housing demand shocks and not much by the responses to other shocks.

As explained earlier, the MCIs are a weighted average of current and past levels of the short- term interest rate, the term spread (or the longterm interest rate), and real house price growth. To show the relative importance of the three components, Table 3 gives the sum of the weights on current and past (up-to-8-quarter) lagged values of each. As in Figure 7A, using annual GDP and inflation as target variable, the MCIs of CLMM and BT are, respectively, calculated based on the short-term interest rate (the first panel); the shortand long-term interest rates (the second panel); and the short- and long-term interest rates, and real house price growth (the third panel). A few 


\section{Figure 7B}

\section{MCls of CLMM and BT, LVAR}
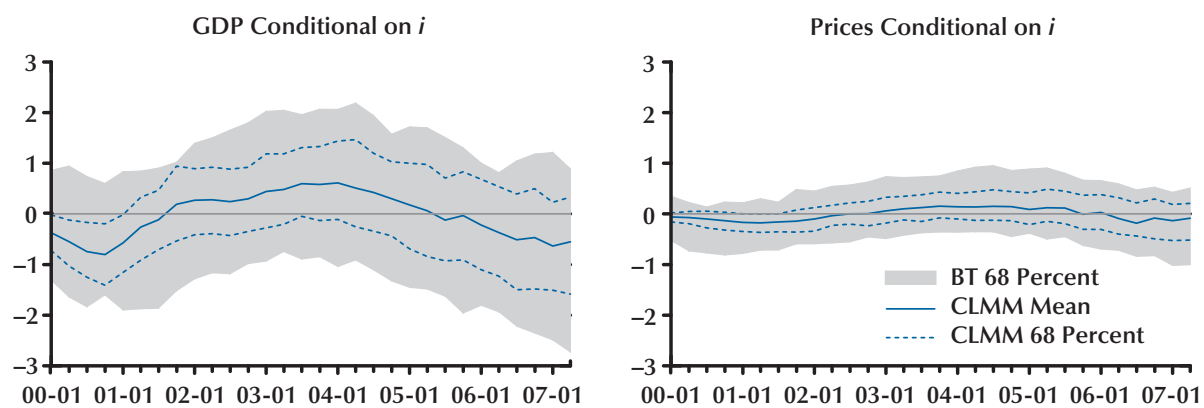

GDP Conditional on $i, s$
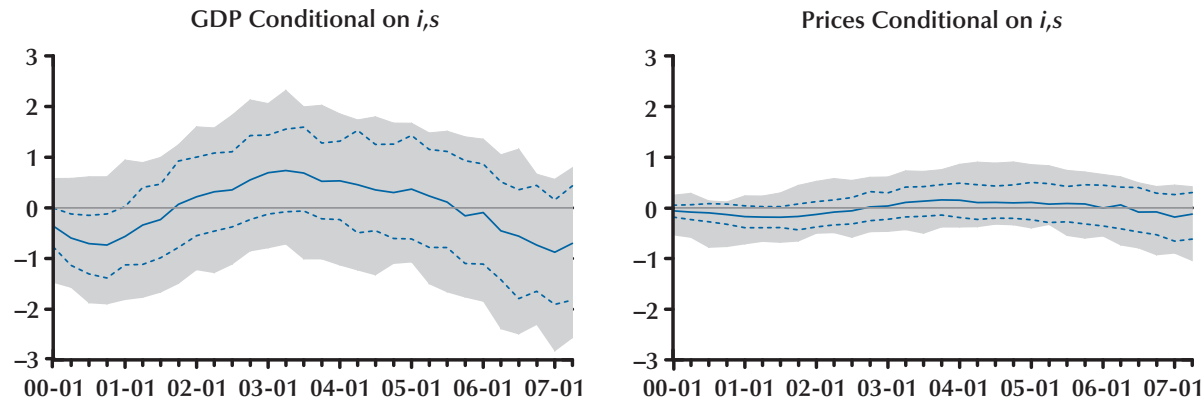

GDP Conditional on $i, s, h p-p$

Prices Conditional on $i, s, h p-p$
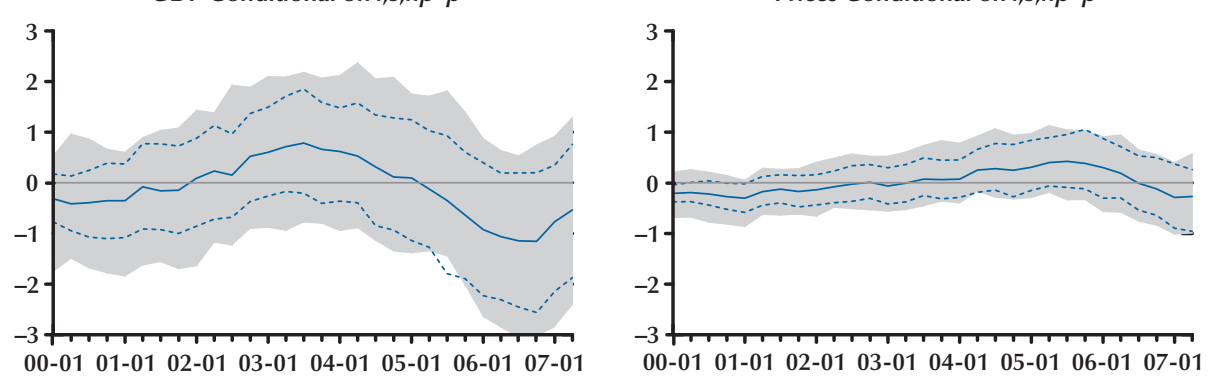

\section{Table 3}

\section{8-Quarter Sum of MCI Weights, DVAR}

\begin{tabular}{|c|c|c|c|c|c|c|}
\hline & \multirow{2}{*}{$\frac{\mathbf{M C l}_{\boldsymbol{i}}}{\text { Short rate (i) }}$} & \multicolumn{2}{|c|}{$\mathbf{M C l}_{i, s}$} & \multicolumn{3}{|c|}{$\mathrm{MCl}_{i, s, h p-p}$} \\
\hline & & Short rate & Long rate $(s)$ & Short rate & Long rate & House prices $(h p-p)$ \\
\hline CLMM-GDP & -0.162 & -0.201 & 0.090 & -0.198 & 0.102 & 0.000 \\
\hline BT-GDP & -0.198 & -0.190 & 0.074 & -0.194 & 0.102 & 0.003 \\
\hline CLMM-Inflation & -0.046 & -0.142 & 0.162 & -0.148 & 0.250 & 0.056 \\
\hline BT-Inflation & -0.154 & -0.182 & 0.168 & -0.087 & 0.180 & 0.083 \\
\hline
\end{tabular}


observations are noteworthy. First, taking only the short-term interest rate as an indicator of the policy stance, it is clear that on average an observed increase in the interest rate above its steady-state value indicates a restrictive policy stance with respect to both GDP growth and inflation. This is, in particular, the case when the short-term interest rate is assumed to be driven by the three identified exogenous shocks (as in the MCI of BT). However, if the full endogenous nature of the nominal interest rate is taken into account (as in the MCI of CLMM), this is less the case and more so for inflation than for growth. The reason is that, because of the central bank's reaction function, the short-term interest rate is likely to increase in response to shocks that drive up future GDP growth and inflation. In this case, a rise in interest rates may even suggest an easing of the policy stance if interest rates do not rise enough to offset the pickup in growth and inflation. To the extent that changes in the nominal interest rate reflect higher inflation and inflation expectations, this argument is particularly strong when expected inflation is the target.

In the second panel of Table 3 , adding the long-term interest rate slightly changes the picture. Keeping the long-term interest rate constant, observing a 1-percentage-point increase in the short-term interest rate for 8 quarters signals a fall in GDP growth of about 20 basis points over the next year and a fall in inflation of somewhat less over the next two years. In contrast, keeping the short-term rate constant, a rise in the longterm interest rate by 1 percentage point signals lax monetary policy, as it predicts a rise in both GDP growth (up to 9 basis points) and inflation (up to 16 basis points) above steady state.

Finally, the far-right panel of Table 3 shows the weights when real house prices are included in the MCIs also. Their addition has little effect on the weights on interest rates. The upper rows show that the weight on real house price growth is close to zero when the target variable is GDP growth. This is indeed similar to the results in Figure 7A, which show that the actual MCIs do not change very much. However, when annual inflation over two years is the target variable, there is a significant weight on house prices: A
5 -percentage-point rise in the growth rate of real house prices signals a 30- to 40-basis-point rise in annual inflation According to the weights, such a rise in house prices would call for a substantially higher short-term rate (of about 2 percentage points) in order to have neutral monetary conditions.

\section{CONCLUSIONS}

In this paper, we examine the role of housing investment and house prices in U.S. business cycles since the second half of the 1980s using an identified Bayesian VAR. We find that housing demand shocks have significant effects on housing investment and house prices, but overall these shocks have had only a limited effect on the performance of the U.S. economy in terms of aggregate growth and inflation in line with the empirical literature. There is also evidence that monetary policy has significant effects on housing investment and house prices and that easy monetary policy designed to stave off perceived risks of deflation in 2002-04 has contributed to the boom in the housing market in 2004 and 2005. However, again, the effect on the overall economy was limited. A counterfactual simulation suggests that without those policy shocks inflation would have been about 25 basis points lower at the end of 2006.

In order to examine the effect of house prices on monetary conditions, we implement a methodology proposed by Céspedes et al. (2006). This methodology consists of calculating the forecast of a target variable (expected GDP growth or expected inflation) conditional on the observed path of monetary conditions, including the shortterm interest rates, the term spread, and house prices. We show that, in spite of the endogeneity of house prices to both the state of the economy and the level of interest rates, taking house prices into account may sharpen the inference about the stance of monetary policy. Given the uncertainty about the sources of business cycle fluctuations and the effect of the various shocks (including housing demand shocks) on the economy, uncertainty regarding the stance of monetary policy 
remains high. Nevertheless, taking the development of house prices into account, there is some indication that monetary conditions may have been too loose in 2004 and were relatively tight in the summer of 2007.

Various caveats regarding the methodology we use in this paper are worth mentioning. First, all the analysis presented in this paper is insample and ex post. Although this is helpful in trying to understand past developments, this does not prove the methodology is sufficient for realtime analysis. For this we need to extend the analysis to a real-time context. Second, the statistical model we use to interpret the U.S. housing market and business cycle is basically a linear one. It has been argued that costly asset price booms and busts are fundamentally of an asymmetric nature. Our linear methodology is not able to handle such nonlinearities. Third, the robustness of the analysis to different identification schemes for the structural shocks needs to be further examined. We hope to shed light on some of these issues in further analysis.

\section{REFERENCES}

Batini, Nicolleta and Turnbull, Kenny. "A Dynamic Monetary Conditions Index for the UK." Journal of Policy Modeling, June 2002, 24(3), pp. 257-81.

Carroll, Christopher D.; Otsuka, Misuzu and Slacalek, Jirka. "How Large Is the Housing Wealth Effect? A New Approach.” NBER Working Paper 12746, National Bureau of Economic Research, 2006.

Céspedes, Brisne; Lima, Elcyon; Maka, Alexis and Mendonça, Mario J.C. "Conditional Forecasts and the Measurement of Monetary Policy Stance in Brazil.” Unpublished manuscript, 2006.

Clarida, Richard; Galí, Jordi and Gertler, Mark. "The Science of Monetary Policy: A New Keynesian Perspective." Journal of Economic Literature, December 1999, 37(4), pp. 1661-707.

Del Negro, Marco and Otrok, Christopher. "99 Luftballons: Monetary Policy and the House Price
Boom Across U.S. States." Journal of Monetary Economics, October 2007, 54(7), pp. 1962-85.

Doan, Thomas; Litterman, Robert B. and Sims, Christopher. "Forecasting and Conditional Projection Using Realistic Prior Distributions." Econometric Reviews, 1984, 3(1), pp. 1-100.

Duguay, Pierre. "Empirical Evidence on the Strength of the Monetary Transmission Mechanism in Canada: An Aggregate Approach.” Journal of Monetary Economics, February 1994, 33(1), pp. 39-61.

Dynan, Karen E.; Elmendorf, Douglas and Sichel, Daniel E. "Can Financial Innovation Help to Explain the Reduced Volatility of Economic Activity?" Journal of Monetary Economics, January 2006, 53(1), pp. 123-50.

Erceg, Christopher J. and Levin, Andrew T. "Optimal Monetary Policy with Durable and Non-durable Goods.” International Finance Discussion Paper No. 748, Board of Governors of the Federal Reserve System, 2002.

Freedman, Charles. "The Use of Indicators and the Monetary Conditions Index in Canada," in T.J.T. Baliño and C. Cottarelli, eds., Frameworks for Monetary Stability: Policy Issues and Country Experiences. Washington, DC: International Monetary Fund, 1994, pp. 458-76.

Freedman, Charles. "The Canadian Experience with Targets for Reducing and Controlling Inflation," in L. Leiderman and L. Svensson, eds., Inflation Targets. London: Centre for Educational Policy Research, 1995a.

Freedman, Charles. "The Role of Monetary Conditions and the Monetary Conditions Index in the Conduct of Policy." Bank of Canada Review, Autumn 1995b, pp. 53-59.

Gerlach, Stefan and Smets, Frank. "MCIs and Monetary Policy." European Economic Review, October 2000, 44(9), pp. 1677-1700.

Goodhart, Charles and Hofmann, Boris. "Financial Conditions Indices," in Charles Goodhart, ed., House Prices and the Macroeconomy: Implications 


\section{Jarociński and Smets}

for Banking and Price Stability. Chap. 3: Oxford: Oxford University Press, 2007.

Iacoviello, Matteo and Neri, Stefano. "The Role of Housing Collateral in an Estimated Two-Sector Model of the U.S. Economy.” Working Papers in Economics 659, Boston College Department of Economics, 2007.

Kohn, Donald L. "Success and Failure of Monetary Policy since the 1950s." Presented at the Deutsche Bundesbank conference Monetary Policy over Fifty Years, a conference to mark the fiftieth anniversary of the Deutsche Bundesbank, Frankfurt, Germany, September 21, 2007.

Leamer, Edward E. "Housing and the Business Cycle." Presented at the Federal Reserve Bank of Kansas City symposium Housing, Housing Finance, and Monetary Policy, Jackson Hole, WY, August 30September 1, 2007.

McConnell, Margaret M. and Pérez-Quirós, Gabriel. "Output Fluctuations in the United States: What Has Changed Since the Early 1980s?" American Economic Review, December 2000, 90(5), pp. 1464-76.

Mishkin, Frederic S. "Housing and the Monetary Transmission Mechanism." Presented at the Federal Reserve Bank of Kansas City symposium Housing, Housing Finance, and Monetary Policy, Jackson Hole, WY, August 30-September 1, 2007.

Mojon, Benoit. "Monetary Policy, Output Composition, and the Great Moderation.” Working Paper WP 2007-07, Federal Reserve Bank of Chicago, 2007.
Muellbauer, John. "Housing and Consumer Behaviour." Presented at the Federal Reserve Bank of Kansas City symposium Housing, Housing Finance, and Monetary Policy, Jackson Hole, WY, August 30-September 1, 2007.

Slacalek, Jirka. "What Drives Personal Consumption? The Role of Housing and Financial Wealth." Unpublished manuscript, November 2006.

Taylor, John B. "Housing and Monetary Policy." Panel discussion at the Federal Reserve Bank of Kansas City symposium Housing, Housing Finance, and Monetary Policy, Jackson Hole, WY, August 30September 1, 2007.

Topel, Robert. H. and Rosen, Sherwin. "Housing Investment in the United States." Journal of Political Economy, August 1988, 96(4), pp. 718-40.

Uhlig, Harald. "What Are the Effects of Monetary Policy on Output? Results from an Agnostic Identification Procedure.” Journal of Monetary Economics, March 2005, 52(2), pp. 381-419.

Villani, Mattias. "Steady-State Priors for Vector Autogressions." Journal of Applied Econometrics, 2008 (forthcoming).

Waggoner, Daniel F. and Zha, Tao. (1999). "Conditional Forecasts in Dynamic Multivariate Models." Review of Economics and Statistics, November 1999, 81(4), pp. 639-51. 


\section{APPENDIX: DATA AND SOURCES}

Real GDP: real GDP, 3 decimal (GDPC96), seasonally adjusted annual rate, quarterly, billions of chained 2000 dollars.

SOURCE: U.S. Department of Commerce: Bureau of Economic Analysis (BEA) data from Federal Reserve Economic Data (FRED; http://research.stlouisfed.org/fred2/).

Real consumption: real personal consumption expenditures (PCECC96), seasonally adjusted annual rate, quarterly, billions of chained 2000 dollars.

SOURCE: BEA data from FRED.

GDP deflator: GDP: implicit price deflator (GDPDEF), seasonally adjusted, quarterly, index $2000=100$. SOURCE: BEA data from FRED.

Federal funds rate: effective federal funds rate (FEDFUNDS), monthly, percent, averages of daily figures. SOURCE: Board of Governors of the Federal Reserve System data from FRED (averaged over 3 months of the quarter).

Long-term interest rate: 10 -year Treasury constant maturity rate (GS10), monthly, percent, averages of business days.

SOURCE: Board of Governors of the Federal Reserve System data from FRED (averaged over 3 months of the quarter).

S\&P/Case-Shiller U.S. National Home Price Index: quarterly, based on repeated sales.

SOURCE: http://www.standardandpoors.com, available since 1987.

M2: M2 money stock (M2NS), not seasonally adjusted, monthly, billions of dollars.

SOURCE: Board of Governors of the Federal Reserve System data from FRED (averaged over 3 months of the quarter).

Real private residential fixed investment: 3 Decimal, (PRFIC96), seasonally adjusted annual rate, quarterly, billions of chained 2000 dollars.

SOURCE: BEA data from FRED.

Commodity price index: Dow Jones spot average, quarterly.

SOURCE: Global Financial Data; www.globalfinancialdata.com.

In the VAR, we use the interest rate spread, computed as the difference between the long interest rate and the federal funds rate, house prices deflated relative to the GDP deflator, and the ratio of real private residential fixed investment to real GDP. All the variables, except for the short-term interest rate, spread, and housing investment, enter either in log levels or log differences (annualized), depending on the VAR specification indicated. 
